\title{
Impact of Siberian observations on the optimization of surface $\mathrm{CO}_{2}$ flux
}

\author{
Jinwoong Kim ${ }^{1, \text { a }}$, Hyun Mee Kim ${ }^{1}$, Chun-Ho Cho ${ }^{2}$, Kyung-On Boo ${ }^{2}$, Andrew R. Jacobson ${ }^{3,4}$, Motoki Sasakawa ${ }^{5}$, \\ Toshinobu Machida ${ }^{5}$, Mikhail Arshinov ${ }^{6}$, and Nikolay Fedoseev ${ }^{7}$ \\ ${ }^{1}$ Department of Atmospheric Sciences, Yonsei University, Seoul, South Korea \\ ${ }^{2}$ National Institute of Meteorological Sciences, Jeju, South Korea \\ ${ }^{3}$ Earth System Research Laboratory, National Oceanic and Atmospheric Administration, Boulder, CO, USA \\ ${ }^{4}$ Cooperative Institute for Research in Environmental Sciences, University of Colorado, Boulder, CO, USA \\ ${ }^{5}$ Center for Global Environmental Research, National Institute for Environment Studies, Tsukuba, Japan \\ ${ }^{6}$ V. E. Zuev Institute of Atmospheric Optics, Russian Academy of Sciences, Tomsk, Russia \\ ${ }^{7}$ Melnikov Permafrost Institute, Russian Academy of Sciences, Yakutsk, Russia \\ ${ }^{a}$ currently at: Climate Research Division, Environment and Climate Change Canada, Toronto, Canada
}

Correspondence to: Hyun Mee Kim (khm@yonsei.ac.kr)

Received: 26 October 2015 - Discussion started: 22 February 2016

Revised: 18 January 2017 - Accepted: 18 January 2017 - Published: 24 February 2017

\begin{abstract}
To investigate the effect of additional $\mathrm{CO}_{2}$ observations in the Siberia region on the Asian and global surface $\mathrm{CO}_{2}$ flux analyses, two experiments using different observation data sets were performed for 2000-2009. One experiment was conducted using a data set that includes additional observations of Siberian tower measurements (JapanRussia Siberian Tall Tower Inland Observation Network: JRSTATION), and the other experiment was conducted using a data set without the above additional observations. The results show that the global balance of the sources and sinks of surface $\mathrm{CO}_{2}$ fluxes was maintained for both experiments with and without the additional observations. While the magnitude of the optimized surface $\mathrm{CO}_{2}$ flux uptake and flux uncertainty in Siberia decreased from $-1.17 \pm 0.93$ to $-0.77 \pm 0.70 \mathrm{Pg} \mathrm{Cyr}^{-1}$, the magnitude of the optimized surface $\mathrm{CO}_{2}$ flux uptake in the other regions (e.g., Europe) of the Northern Hemisphere (NH) land increased for the experiment with the additional observations, which affect the longitudinal distribution of the total NH sinks. This change was mostly caused by changes in the magnitudes of surface $\mathrm{CO}_{2}$ flux in June and July. The observation impact measured by uncertainty reduction and self-sensitivity tests shows that additional observations provide useful information on the estimated surface $\mathrm{CO}_{2}$ flux. The average uncertainty reduction of the conifer forest of Eurasian boreal (EB) is $29.1 \%$ and
\end{abstract}

the average self-sensitivities at the JR-STATION sites are approximately $60 \%$ larger than those at the towers in North America. It is expected that the Siberian observations play an important role in estimating surface $\mathrm{CO}_{2}$ flux in the $\mathrm{NH}$ land (e.g., Siberia and Europe) in the future.

\section{Introduction}

The terrestrial ecosystem in the Northern Hemisphere (NH) plays an important role in the global carbon balance (Hayes et al., 2011; Le Quéré et al., 2015). Especially Siberia is considered to be the one of the largest $\mathrm{CO}_{2}$ uptake regions and reservoirs due to its forest area (Schulze et al., 1999; Houghton et al., 2007; Tarnocai et al., 2009; Kurganova et al., 2010; Schepaschenko et al., 2011) and the global significance of its dynamics and interactions with the climate (Quegan et al., 2011). Therefore, it is important to accurately estimate the surface $\mathrm{CO}_{2}$ fluxes in this region. For instance, Dolman et al. (2012) estimated terrestrial carbon budget of Russia, Ukraine, Belarus, and Kazakhstan using inventorybased, eddy covariance, and inversion methods and showed that the carbon budgets produced by three methods agree within their uncertainty bounds. 
To estimate the surface $\mathrm{CO}_{2}$ flux, atmospheric $\mathrm{CO}_{2}$ inversion studies are conducted using atmospheric transport models and atmospheric $\mathrm{CO}_{2}$ observations (Gurney et al., 2002; Peylin et al., 2013). However, prior emission, measurement error of observation, observation operator including model transport, and representative error affect the uncertainty of atmospheric inversion results (Engelen et al., 2002; Berchet et al., 2015a). Along these factors, large uncertainties remain in the estimated surface $\mathrm{CO}_{2}$ fluxes due to the sparseness of current surface $\mathrm{CO}_{2}$ measurements assimilated by inverse models (Peters et al., 2010; Bruhwiler et al., 2011). Peylin et al. (2013) performed an intercomparison study of estimated surface $\mathrm{CO}_{2}$ fluxes from 11 different inversion systems. The results showed that the estimated surface $\mathrm{CO}_{2}$ flux uptake in the $\mathrm{NH}$, where the atmospheric $\mathrm{CO}_{2}$ network is dense, is similar across the inversion systems; meanwhile, the established flux is noticeably different across the inversion systems for the tropics and the Southern Hemisphere ( $\mathrm{SH})$, where the atmospheric $\mathrm{CO}_{2}$ network is sparse.

Regionally, however, the longitudinal breakdown of all the $\mathrm{NH}$ sinks appears to be much more variable than the total flux itself. Therefore, additional observations in a sparse $\mathrm{CO}_{2} \mathrm{ob}-$ servation network region are necessary to reduce uncertainty in estimating the surface $\mathrm{CO}_{2}$ flux. Maksyutov et al. (2003) showed that additional observations in the Asia region show the largest effect and reduce the uncertainty in the estimated regional $\mathrm{CO}_{2}$ fluxes for Siberia during 1992-1996 by timeindependent synthesis inversion. Chevallier et al. (2010) also argued that an extension of the observation network toward eastern Europe and Siberia is necessary to reduce uncertainty in estimated fluxes by inversion methods. Despite the necessity of additional observations in this region, only a few atmospheric $\mathrm{CO}_{2}$ inversion studies have been conducted using observations in this region due to the deficiency of observations (Quegan et al., 2011).

Meanwhile, Reuter et al. (2014) and Feng et al. (2016) reported that the European terrestrial $\mathrm{CO}_{2}$ uptake inferred by the satellite-retrieved dry-air column-average mole fraction of $\mathrm{CO}_{2}\left(\mathrm{XCO}_{2}\right)$ is larger than that inferred by a bottom-up inventory approach or inverse modeling systems using surfacebased $\mathrm{CO}_{2}$ atmospheric concentrations. Though a broad spatial coverage of $\mathrm{XCO}_{2}$ from satellite radiance observations provides useful information for inversion systems in quantifying surface $\mathrm{CO}_{2}$ fluxes at various scales (which is not provided by ground-based measurements), the current $\mathrm{XCO}_{2}$ has low accuracy and regional biases of a few tenths of ppm (parts per million), which may hamper the accuracy of estimated surface $\mathrm{CO}_{2}$ fluxes (Miller et al., 2007; Chevallier et al., 2007). Therefore, in situ observations determined by surface measurements are necessary to more accurately estimate the surface $\mathrm{CO}_{2}$ flux in the inverse models.

To supply additional observations over Siberia to inverse modeling studies, several efforts to observe the atmospheric $\mathrm{CO}_{2}$ concentrations in Siberia have been conducted. For example, the Max Planck Institute (MPI) oper- ates a tower (since April 2009), preceded by aircraft measurements (from 1998 to 2005 with 12- to 21-day intervals) at Zotino (ZOTTO; $60.75^{\circ} \mathrm{N}, 89.38^{\circ} \mathrm{E}$ ) (Lloyd et al., 2002; Winderlich et al., 2010). In addition, the Airborne Extensive Regional Observations in Siberia (YAK-AEROSIB) aircraft campaign in 2006 (Paris et al., 2008) and Trans-Siberian Observation Into the Chemistry of the Atmosphere (TROICA) project (Turnbull et al., 2009) have measured $\mathrm{CO}_{2}$ and other chemical species. However, except Zotino, which has multiyear measurements, these data collected during specific seasons or over only a few years do not provide the long-term $\mathrm{CO}_{2}$ concentration data necessary to be used as a constraint in the inverse modeling system.

The Center for Global Environmental Research (CGER) of the National Institute for Environmental Studies (NIES) of Japan with the cooperation of the Russian Academy of Science (RAS) constructed a tower network called the JapanRussia Siberian Tall Tower Inland Observation Network (JRSTATION) in 2002 to measure the continuous $\mathrm{CO}_{2}$ and $\mathrm{CH}_{4}$ concentrations (eight towers in central Siberia and one tower in eastern Siberia) (Sasakawa et al., 2010, 2013). The vertical profile of $\mathrm{CO}_{2}$ concentrations from the planetary boundary layer (PBL) to the lower free troposphere is also measured by aircraft at one site of the JR-STATION sites (Sasakawa et al., 2010, 2013). Saeki et al. (2013) estimated the monthly surface $\mathrm{CO}_{2}$ flux for 68 subcontinental regions by using the fixed-lag Kalman smoother and NIES-TM transport model with JR-STATION data. They reported that the inclusion of additional Siberian observation data has an impact on the inversion results showing larger interannual variability over northeastern Europe as well as Siberia, and reduces the uncertainty of surface $\mathrm{CO}_{2}$ uptake. Meanwhile, Berchet et al. (2015b) estimated regional $\mathrm{CH}_{4}$ fluxes over Siberia in 2010 by using JR-STATION data.

CarbonTracker, developed by the National Oceanic and Atmospheric Administration Earth System Research Laboratory (NOAA ESRL) (Peters et al., 2007), is an atmospheric $\mathrm{CO}_{2}$ inverse modeling system that estimates optimized weekly surface $\mathrm{CO}_{2}$ flux on a $1^{\circ} \times 1^{\circ}$ horizontal resolution by using the ensemble Kalman filter (EnKF) (Evensen, 1994). Since the original CarbonTracker release (Peters et al., 2007), a series of improvements have been made with subsequent releases. These include increasing the number of sites from which $\mathrm{CO}_{2}$ data are assimilated, increasing the resolution of atmospheric transport, improving the simulation of atmospheric convection in TM5 (Krol et al., 2005), which is the transport model used in CarbonTracker, and the use of multiple first-guess flux models to estimate sensitivity to priors. These improvements are documented at http://carbontracker.noaa.gov. Several studies have focused on Asia using CarbonTracker (Kim et al., 2012, 2014a, b; Zhang et al., 2014a, b). Schneising et al. (2011) showed that SCanning Imaging Absorption spectroMeter for Atmospheric CHartographY (SCIAMACHY) retrieval data indicate a stronger North American boreal forest uptake and 
weaker Russian boreal forest uptake compared to CarbonTracker within their uncertainties. On the other hand, Zhang et al. (2014b) estimated surface $\mathrm{CO}_{2}$ fluxes in Asia by assimilating CONTRAIL (Machida et al., 2008) aircraft $\mathrm{CO}_{2}$ measurements into the CarbonTracker framework. The CONTRAIL measurements include ascending/descending vertical profiles and cruise data below tropopause. The results show that surface $\mathrm{CO}_{2}$ uptake over the Eurasian boreal (EB) re-

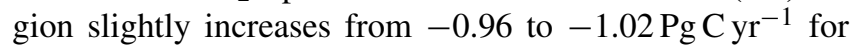
the period 2006-2010 when aircraft $\mathrm{CO}_{2}$ measurements were assimilated. However, the surface measurement data over the EB region are still not used in the study by Zhang et al. (2014b). Using an influence matrix calculation, Kim et al. (2014b) showed that comprehensive coverage of additional observations in an observation-sparse region, e.g., Siberia, is necessary to estimate the surface $\mathrm{CO}_{2}$ flux in these areas as accurately as that obtained for North America in the CarbonTracker framework.

In this study, the impact of additional Siberian observations on the optimized surface $\mathrm{CO}_{2}$ flux over the globe and Asian region within CarbonTracker (the version of CarbonTracker used in this study is based on the CarbonTracker 2010 release) is investigated by comparing the results of estimated surface $\mathrm{CO}_{2}$ fluxes from two experiments with and without Siberian observations. Section 2 presents the methodology including a priori flux data, atmospheric $\mathrm{CO}_{2}$ observations, and experimental framework. Section 3 presents the results, and Sect. 4 provides a summary and conclusions.

\section{Methodology}

\subsection{Inversion method}

CarbonTracker is an inverse modeling system developed by Peters et al. (2007). Optimized surface $\mathrm{CO}_{2}$ fluxes with a $1^{\circ} \times 1^{\circ}$ horizontal resolution are calculated as follows:

$$
\begin{aligned}
F(x, y, t) & =\lambda_{r} \cdot F_{\mathrm{bio}}(x, y, t)+\lambda_{r} \cdot F_{\mathrm{ocn}}(x, y, t) \\
& +F_{\mathrm{ff}}(x, y, t)+F_{\text {fire }}(x, y, t)
\end{aligned}
$$

where $\quad F_{\text {bio }}(x, y, t), \quad F_{\text {ocn }}(x, y, t), \quad F_{\mathrm{ff}}(x, y, t), \quad$ and $F_{\text {fire }}(x, y, t)$ are a priori emissions from the biosphere, the ocean, fossil fuel, and fires. $\lambda_{r}$ is the scaling factor to be optimized in the data assimilation process, corresponding to 156 regions around the globe (126 land and 30 ocean regions). On the land, the ecoregions are defined as the combination of 11 land regions of Transcom regions (Gurney et al., 2002) and 19 with land-surface characterization based on Olson et al. (1992). Inappropriate combinations of Transcom regions and Olson types are excluded. In the ocean, 30 ocean regions are defined following Jacobson et al. (2007). The scaling factor spans 5 weeks with a 1-week resolution. Several previous studies for CarbonTracker (e.g., Peters et al., 2007, 2010, Kim et al., 2012, 2014a, b; Zhang et al., 2014a, b; van der Laan-Luijkx et al., 2015) showed that 5 weeks of lag and 1-week time resolution are appropriate for optimizing the surface $\mathrm{CO}_{2}$ fluxes. In each assimilation cycle (i.e., analysis step), the entire scaling factor for 5 weeks is updated by 1 -week observations measured in the most recent week by a time-stepping approach. The smoother window moves forward by 1 week at each assimilation cycle. After 5 assimilation cycles, the first part of the scaling factor analyzed by 5-week observations is regarded as the optimized scaling factor. More detailed information of the assimilation process can be found in Kim et al. (2014b).

The ensemble Kalman filter (EnKF) data assimilation method used in CarbonTracker is the ensemble square root filter (EnSRF) suggested by Whitaker and Hamill (2002). The analysis equation for data assimilation is expressed as

$\boldsymbol{x}^{\mathrm{a}}=\mathbf{K} \boldsymbol{y}^{\mathrm{o}}+\left(\mathbf{I}_{n}-\mathbf{K} \mathbf{H}\right) \boldsymbol{x}^{\mathrm{b}}$,

where $\boldsymbol{x}^{\mathrm{a}}$ is the $n$-dimensional analysis (posterior) state vector; $\boldsymbol{y}^{\mathrm{o}}$ is the $p$-dimensional observation vector (atmospheric $\mathrm{CO}_{2}$ observations); $\mathbf{K}$ is the $n \times p$ dimensional Kalman gain; $\mathbf{I}_{n}$ is the identity matrix; $\mathbf{H}$ is the linearized observation operator, which transforms the information in the model space to the information in the observation space; and $\boldsymbol{x}^{\mathrm{b}}$ is the background state vector. In CarbonTracker, the state vector corresponds to the scaling factor. The Kalman gain $\mathbf{K}$ is defined as

$\mathbf{K}=\left(\mathbf{P}^{\mathrm{b}} \mathbf{H}^{\mathrm{T}}\right)\left(\mathbf{H} \mathbf{P}^{\mathrm{b}} \mathbf{H}^{\mathrm{T}}+\mathbf{R}\right)^{-1}$,

where $\mathbf{P}^{\mathrm{b}}$ is the background error covariance; $\mathbf{R}$ is the observation error covariance or model-data mismatch, which is predefined at each observation site. $\mathbf{P}^{\mathrm{b}} \mathbf{H}^{\mathrm{T}}$ and $\mathbf{H} \mathbf{P}^{\mathrm{b}} \mathbf{H}^{\mathrm{T}}$ in Eq. (3) can be calculated as

$$
\begin{aligned}
\mathbf{P H}^{\mathrm{T}} & \approx \frac{1}{m-1}\left(\boldsymbol{x}_{1}^{\prime}, \boldsymbol{x}_{2}{ }_{2}, \ldots, \boldsymbol{x}_{m}{ }_{m}\right) \\
& \times\left(\mathbf{H} \boldsymbol{x}_{1}, \mathbf{H} \boldsymbol{x}_{2}{ }_{2}, \ldots, \mathbf{H} \boldsymbol{x}_{m}^{\prime}\right)^{\mathrm{T}}, \\
\mathbf{H P H}^{\mathrm{T}} & \approx \frac{1}{m-1}\left(\mathbf{H} \boldsymbol{x}_{1}{ }_{1}, \mathbf{H} \boldsymbol{x}_{2}{ }_{2}, \ldots, \mathbf{H} \boldsymbol{x}_{m}{ }_{m}\right) \\
& \times\left(\mathbf{H} \boldsymbol{x}_{1}, \mathbf{H} \boldsymbol{x}_{2}{ }_{2}, \ldots, \mathbf{H} \boldsymbol{x}_{m}{ }_{m}\right)^{\mathrm{T}},
\end{aligned}
$$

where $m$ is the number of ensembles and 'denotes the perturbation of ensemble mean.

The sampling error caused by the limited ensemble size may degrade the analysis accuracy. To reduce the impact of sampling error in the EnKF, the covariance localization method is used (Houtekamer and Mitchell, 2001). The localization is not applied to marine boundary layer (MBL) sites, e.g., observation sites in Antarctica, because the MBL sites are considered to include information on large footprints of flux signals (Peters et al., 2007). The physical distance between the scaling factors cannot be defined. Therefore, localization is performed based on the linear correlation coefficient between the ensemble of the scaling factor and the ensemble of the model $\mathrm{CO}_{2}$ concentration (Peters et al., 2007). 


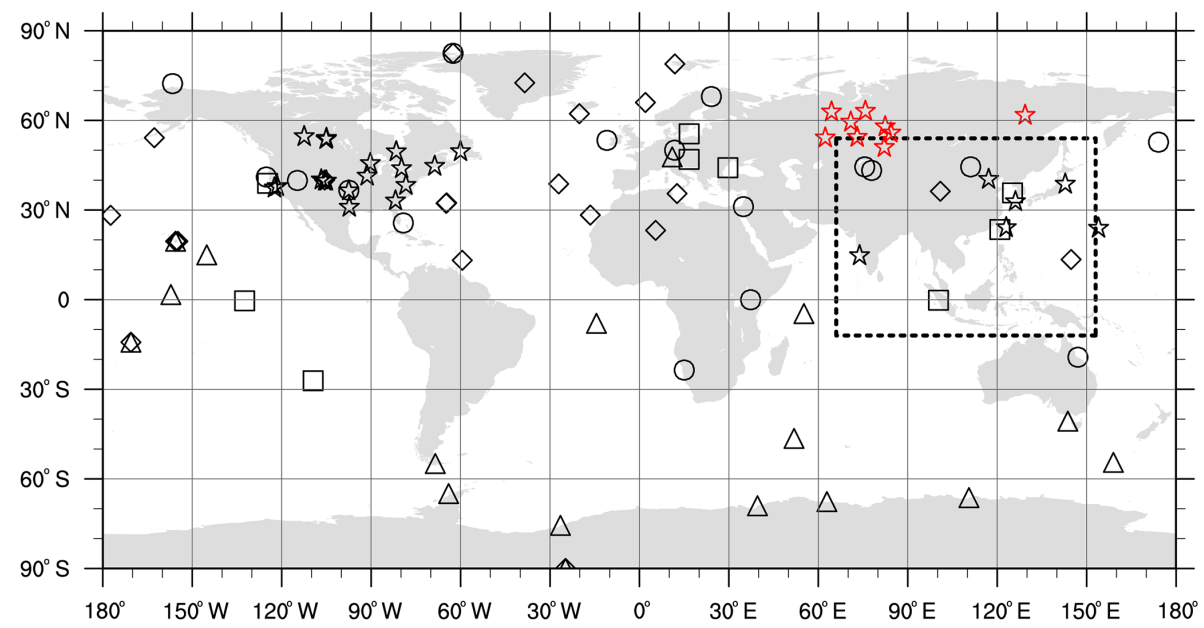

Figure 1. Observation networks of $\mathrm{CO}_{2}$ concentrations around the globe and the nested domain of the TM5 transport model over Asia (dashed box). Each observation site is assigned to different categories $(\triangle$ : MBL; $\bigcirc$ : continental; $\diamond$ : mixed land/ocean and mountain; $乞 \tau$ : continuous; $\square$ : difficult). JR-STATION observation sites are represented in red.

A statistical significance test is performed on the linear correlation coefficient with a cutoff at a $95 \%$ significance in a Student's $t$ test. Then, the components of Kalman gain with an insignificant statistical value are set to zero.

After one analysis step is completed, the new mean scaling factor that serves as the background scaling factor for next analysis cycle is predicted as

$\lambda_{t}^{b}=\frac{\left(\lambda_{t-2}^{a}+\lambda_{t-1}^{a}+1\right)}{3}$,

where $\lambda_{t}^{b}$ is a prior mean scaling factor of the current analysis cycle, $\lambda_{t-2}^{a}$ and $\lambda_{t-1}^{a}$ are posterior mean scaling factors of previous cycles. Eq. (6) propagates information from one step to the next step (Peters et al., 2007).

The detailed algorithm of the inversion method used in this study can be found in Peters et al. (2007) and Kim et al. (2014a).

\subsection{A priori flux data}

Four types of a priori and imposed $\mathrm{CO}_{2}$ fluxes used in this study are as follows: (1) first-guess biosphere flux from the Carnegie-Ames-Stanford Approach Global Fire Emissions Database (CASA GFED) version 3.1 (van der Werf et al., 2010). The $3 \mathrm{~h}$ interval net ecosystem exchange (NEE) is calculated from monthly mean net primary production (NPP) and ecosystem respiration (RE) by using a simple temperature $Q_{10}{ }^{1}$ relationship and a linear scaling of photosynthesis with solar radiation (Olsen and Randerson, 2004); (2) the prior ocean flux from air-sea partial pressure differences are based on Jacobson et al. (2007). Short-term flux variability is derived from the atmospheric model wind speeds via

\footnotetext{
${ }^{1}$ It is calculated as $Q_{10}(t)=1.5^{\left(\left(T_{2 m}-T_{0}\right) / 10.0\right)}$, where $t$ is time, $T_{2 \mathrm{~m}}$ is temperature $(\mathrm{K})$ at $2 \mathrm{~m}$, and $T_{0}$ is $273.15 \mathrm{~K}$.
}

the gas transfer coefficient; (3) biomass burning emissions are obtained from GFED v3.1 (van der Werf et al., 2010); (4) the prescribed fossil fuel emission is from the Carbon Dioxide Information and Analysis Center (CDIAC; Boden et al., 2010) and the Emission Database for Global Atmospheric Research (EDGAR; European Commission, 2009) databases. The annual global total fossil fuel emissions are based on CDIAC. Fluxes at $1^{\circ} \times 1^{\circ}$ resolution are spatially distributed according to the EDGAR inventories.

\subsection{Atmospheric $\mathrm{CO}_{2}$ observations}

Atmospheric $\mathrm{CO}_{2}$ mole fraction observations measured at surface observation sites are used in this study. Figure 1 shows the observation network and Table 1 presents observation site information for the Asian and European regions. Three sets of atmospheric $\mathrm{CO}_{2}$ observations data are assimilated: (1) surface $\mathrm{CO}_{2}$ observations distributed by the NOAA ESRL (observation sites operated by NOAA, Environment Canada (EC), the Australian Commonwealth Scientific and Industrial Research Organization (CSIRO), the National Center for Atmospheric Research (NCAR), and Lawrence Berkeley National Laboratory (LBNL) (observation data are available at http://www.esrl.noaa.gov/gmd/ ccgg/obspack/data.php; Masarie et al., 2014); (2) World Data Centre for Greenhouse Gases (WDCGG, http://ds.data. jma.go.jp/wdcgg/); (3) JR-STATION observation data over Siberia operated by CGER/NIES (Sasakawa et al., 2010, 2013). The JR-STATION sites consist of nine towers (eight towers in west Siberia and one tower in east Siberia). Atmospheric air was sampled at four levels on the BRZ tower and at two levels on the other eight towers. At the BRZ (Berezorechka) site in west Siberia, both tower and aircraft measurements are sampled. The light aircraft at the BRZ site 
Table 1. Information on observation sites located in the Asia and Europe region. MDM represents the model-data mismatch, which is the observation error.

\begin{tabular}{|c|c|c|c|c|c|c|}
\hline Site & Location & Latitude & Longitude & $\begin{array}{r}\text { Height } \\
\text { (sampling } \\
\text { height) }(\mathrm{m})\end{array}$ & $\begin{array}{l}\text { Laboratory } \\
\text { (cooperating } \\
\text { agency) }\end{array}$ & $\begin{array}{l}\text { MDM } \\
(\mathrm{ppm})\end{array}$ \\
\hline $\mathrm{AZV}$ & Azovo, Russia & $54.71^{\circ} \mathrm{N}$ & $73.03^{\circ} \mathrm{E}$ & $110(50)$ & NIES & 3 \\
\hline BRZ & Berezorechka, Russia & $56.15^{\circ} \mathrm{N}$ & $84.33^{\circ} \mathrm{E}$ & $168(80)$ & NIES & 3 \\
\hline DEM & Demyanskoe, Russia & $59.79^{\circ} \mathrm{N}$ & $70.87^{\circ} \mathrm{E}$ & $63(63)$ & NIES & 3 \\
\hline IGR & Igrim, Russia & $63.19^{\circ} \mathrm{N}$ & $64.41^{\circ} \mathrm{E}$ & $9(47)$ & NIES & 3 \\
\hline KRS & Karasevoe, Russia & $58.25^{\circ} \mathrm{N}$ & $82.42^{\circ} \mathrm{E}$ & $76(67)$ & NIES & 3 \\
\hline NOY & Noyabrsk, Russia & $63.43^{\circ} \mathrm{N}$ & $75.78^{\circ} \mathrm{E}$ & $108(43)$ & NIES & 3 \\
\hline SVV & Savvushka, Russia & $51.33^{\circ} \mathrm{N}$ & $82.13^{\circ} \mathrm{E}$ & $495(52)$ & NIES & 3 \\
\hline VGN & Vaganovo, Russia & $54.50^{\circ} \mathrm{N}$ & $62.32^{\circ} \mathrm{E}$ & $192(85)$ & NIES & 3 \\
\hline YAK & Yakutsk, Russia & $62.09^{\circ} \mathrm{N}$ & $129.36^{\circ} \mathrm{E}$ & 264(77) & NIES & 3 \\
\hline WLG & Mt. Waliguan, China & $36.29^{\circ} \mathrm{N}$ & $100.9^{\circ} \mathrm{E}$ & 3810 & CMA/ESRL & 1.5 \\
\hline BKT & Bukit Kototabang, Indonesia & $0.20^{\circ} \mathrm{S}$ & $100.32^{\circ} \mathrm{E}$ & 864 & ESRL & 7.5 \\
\hline WIS & Sde Boker, Israel & $31.13^{\circ} \mathrm{N}$ & $34.88^{\circ} \mathrm{E}$ & 400 & ESRL & 2.5 \\
\hline KZD & Sary Taukum, Kazakhstan & $44.45^{\circ} \mathrm{N}$ & $77.57^{\circ} \mathrm{E}$ & 412 & ESRL & 2.5 \\
\hline KZM & Assy Plateau, Kazakhstan & $43.25^{\circ} \mathrm{N}$ & $77.88^{\circ} \mathrm{E}$ & 2519 & ESRL & 2.5 \\
\hline TAP & Tae-ahn Peninsula, South Korea & $36.73^{\circ} \mathrm{N}$ & $126.13^{\circ} \mathrm{E}$ & 20 & ESRL & 5 \\
\hline UUM & Ulaan Uul, Mongolia & $44.45^{\circ} \mathrm{N}$ & $111.10^{\circ} \mathrm{E}$ & 914 & ESRL & 2.5 \\
\hline CRI & Cabo de Rama, India & $15.08^{\circ} \mathrm{N}$ & $73.83^{\circ} \mathrm{E}$ & 60 & CSIRO & 3 \\
\hline LLN & Lulin, Taiwan & $23.47^{\circ} \mathrm{N}$ & $120.87^{\circ} \mathrm{E}$ & 2862 & ESRL & 7.5 \\
\hline SDZ & Shangdianzi, China & $40.39^{\circ} \mathrm{N}$ & $117.07^{\circ} \mathrm{E}$ & 287 & CMA/ESRL & 3 \\
\hline MNM & Minami-Tori-shima, Japan & $24.29^{\circ} \mathrm{N}$ & $153.98^{\circ} \mathrm{E}$ & 8 & JMA & 3 \\
\hline RYO & Ryori, Japan & $39.03^{\circ} \mathrm{N}$ & $141.82^{\circ} \mathrm{E}$ & 260 & JMA & 3 \\
\hline YON & Yonaguni-jima, Japan & $24.47^{\circ} \mathrm{N}$ & $123.02^{\circ} \mathrm{E}$ & 30 & JMA & 3 \\
\hline GSN & Gosan, South Korea & $33.15^{\circ} \mathrm{N}$ & $126.12^{\circ} \mathrm{E}$ & 72 & NIER & 3 \\
\hline BAL & Baltic Sea, Poland & $55.35^{\circ} \mathrm{N}$ & $17.22^{\circ} \mathrm{E}$ & 3 & ESRL (MIR*) & 7.5 \\
\hline BSC & Black Sea, Constanţa, Romania & $44.17^{\circ} \mathrm{N}$ & $28.68^{\circ} \mathrm{E}$ & 3 & ESRL (RMRI*) & 7.5 \\
\hline HUN & Hegyhátsál, Hungary & $46.95^{\circ} \mathrm{N}$ & $16.65^{\circ} \mathrm{E}$ & 248 & ESRL (HMS*) & 7.5 \\
\hline OBN & Obninsk, Russia & $55.11^{\circ} \mathrm{N}$ & $36.60^{\circ} \mathrm{E}$ & 183 & ESRL & 7.5 \\
\hline OXK & Ochsenkopf, Germany & $50.03^{\circ} \mathrm{N}$ & $11.80^{\circ} \mathrm{E}$ & 1022 & ESRL (MPI-BGC**) & 2.5 \\
\hline PAL & Pallas-Sammaltunturi, GAW station, Finland & $67.97^{\circ} \mathrm{N}$ & $24.12^{\circ} \mathrm{E}$ & 560 & ESRL (FMI*) & 2.5 \\
\hline STM & Ocean Station M, Norway & $66.00^{\circ} \mathrm{N}$ & $2.00^{\circ} \mathrm{E}$ & 0 & ESRL (MET Norway*) & 1.5 \\
\hline
\end{tabular}

* Cooperating agencies of observation sites in Europe are Morski Instytut Rybacki (MIR), Romanian Marine Research Institute (RMRI), Hungarian Meteorological Service (HMS), Max Planck Institute for Biogeochemistry (MPI-BGC), Finnish Meteorological Institute (FMI), and Norwegian Meteorological Institute (MET Norway). Cooperating agencies of observation sites outside of Europe are China Meteorological Administration (CMA), Japan Meteorological Agency (JMA), and National Institute of Environmental Research (NIER).

measures the vertical profiles of $\mathrm{CO}_{2}$ from the PBL to the lower free troposphere, and these vertical profiles are used as independent observations for verification.

Sampled $\mathrm{CO}_{2}$ data were calibrated against the NIES 09 $\mathrm{CO}_{2}$ scale, which is lower than the WMO-X2007 $\mathrm{CO}_{2}$ scale by $0.07 \mathrm{ppm}$ at around $360 \mathrm{ppm}$ and consistent in the range between 380 and 400 ppm (Machida et al., 2011). Detailed description of JR-STATION sites can be found in Sasakawa et al. (2010, 2013). Daytime averaged $\mathrm{CO}_{2}$ concentrations (12:00-16:00 LST, representing the time when active vertical mixing occurred in the PBL) for each day from the time series at the highest level of tower measurements are used in the data assimilation.

In CarbonTracker, model-data mismatch (MDM; $\mathbf{R}$ in Eq. 7) is assigned by site categories. The location of each observation site is represented in Fig. 1. The assigned MDM requires that innovation $\chi^{2}$ statistics in Eq. (7) become close to 1 at each observation site (Peters et al., 2007).

$\chi^{2}=\frac{\left(\boldsymbol{y}^{\mathrm{o}}-\mathbf{H} \boldsymbol{x}^{\mathrm{b}}\right)^{2}}{\mathbf{H} \mathbf{P}^{\mathrm{b}} \mathbf{H}^{\mathrm{T}}+\mathbf{R}}$,

where $\boldsymbol{y}^{\mathrm{o}}-\mathbf{H} \boldsymbol{x}^{\mathrm{b}}$ represents the innovation. The site categories and MDM values are assigned the same value as in previous studies (Peters et al., 2007; Kim et al., 2014b; Zhang et al., 2014b): marine boundary layer $(0.75 \mathrm{ppm})$, continental sites $(2.5 \mathrm{ppm})$, mixed land/ocean and mountain sites (1.5 ppm), continuous sites $(3.0 \mathrm{ppm})$, and difficult sites $(7.5 \mathrm{ppm})$ that are located near polluted areas with high anthropogenic $\mathrm{CO}_{2}$ emissions. The continuous site category is generally used for observations measured continuously. For the JR-STATION 


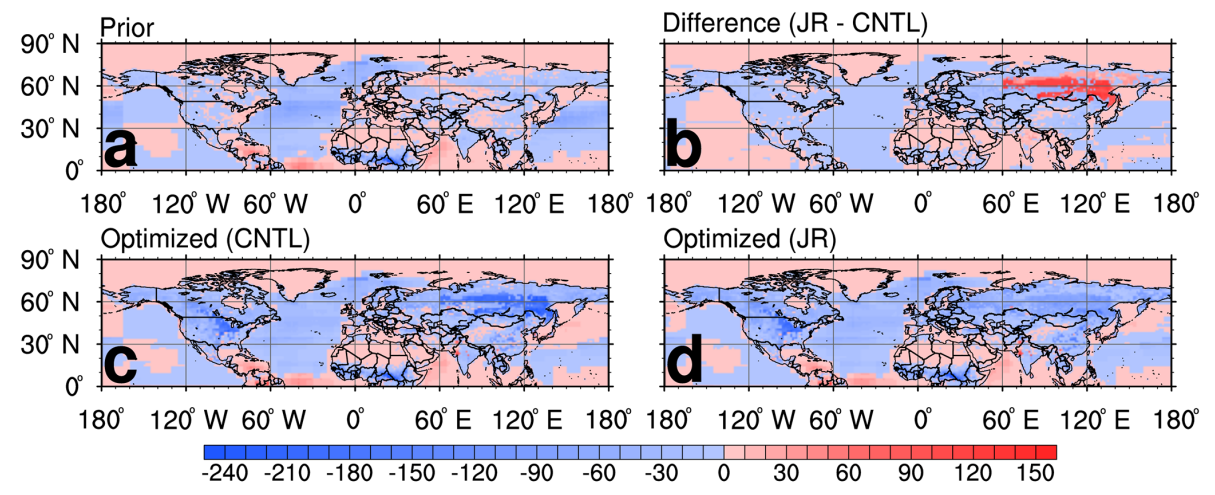

Figure 2. Average biosphere and ocean fluxes $\left(\mathrm{g} \mathrm{C} \mathrm{m}^{-2} \mathrm{yr}^{-1}\right)$ from 2002 to 2009 of (a) the prior flux, (b) the difference between the optimized fluxes in the JR and CNTL experiments, (c) the optimized flux in the CNTL experiment, and (d) the optimized flux in the JR experiment. Blue colors (negative) denote net $\mathrm{CO}_{2}$ flux uptake while red colors (positive) denote net $\mathrm{CO}_{2}$ release to the atmosphere. The difference is calculated by subtracting surface $\mathrm{CO}_{2}$ flux of the CNTL experiment from that of the JR experiment.

sites that have continuous tower measurements, the MDM is set to $3 \mathrm{ppm}$, which is the same as tower measurements in North America.

\subsection{Experimental framework}

Two experiments with different sets of observations are conducted in this study: one experiment, the control (CNTL) experiment, is conducted by using a set of observations without observations in the Siberia region (black-colored observation sites represented in Fig. 1); the other experiment, the JR (Japan-Russia) experiment, is conducted using all available observations including the Siberia data (all observation sites represented in Fig. 1). The TM5 model runs at global $3^{\circ} \times 2^{\circ}$ horizontal resolution and a nesting domain centered in Asia with $1^{\circ} \times 1^{\circ}$ horizontal resolution. The nesting domain is shown in Fig. 1. Meteorological variables for running the TM5 transport model are from the European Centre for Medium-Range Weather Forecasts (ECMWF) forecast model output. The experimental period is from 1 January 2000 to 31 December 2009. The observation data commonly used for the CNTL and JR experiments exist from 2000, but the additional Siberia data for the JR experiment exist from 2002. The number of ensembles is 150 , and the scaling factor includes 5 weeks of lag, as in previous studies (Peters et al., 2007, 2010; Peylin et al., 2013; Kim et al., 2012, 2014a, b; Zhang et al., 2014a, b).

\section{Results}

\subsection{Characteristics of carbon fluxes}

In this section, optimized surface $\mathrm{CO}_{2}$ fluxes inferred from the two experiments are examined. The optimized surface $\mathrm{CO}_{2}$ flux in 2000 and 2001 is excluded from this analysis because 2000 is considered a spin-up year similar to previous studies using CarbonTracker, and JR-STATION data are used since 2002. Only the biosphere and ocean fluxes are presented here because fires (biomass burning) and fossil fuel emissions are not optimized in CarbonTracker.

Figure 2 presents the spatial distribution of the averaged prior and optimized biosphere and ocean fluxes of the two experiments and the difference between the CNTL and JR experiments from 2002 to 2009. The optimized biosphere flux uptakes of the CNTL and JR experiments are globally $1.60-1.61 \mathrm{Pg} \mathrm{C} \mathrm{yr}^{-1}$ greater than the prior flux uptakes (Fig. 2a, c, d; Table 2). The difference in fluxes between the prior and JR experiment is large in EB (Fig. 2a, d) although smaller than that between the prior and CNTL experiment (Fig. 2a, c). The differences in fluxes between the CNTL and JR experiments are large in EB (Siberia) where the new additional observations are assimilated (Fig. 2b). The magnitude of surface $\mathrm{CO}_{2}$ uptakes decreases in that region by assimilating JR-STATION observation data. On the contrary, the average surface $\mathrm{CO}_{2}$ uptakes in other regions, such as North America, Europe, the western North Pacific Ocean, and the Atlantic Ocean, increase by assimilating JR-STATION observation data.

The difference in the optimized $\mathrm{CO}_{2}$ flux between the two experiments is analyzed. Table 2 presents prior and optimized fluxes with their uncertainties for global total, global land, global ocean, NH total, tropics total, Southern Hemisphere total, and Transcom regions in the NH. Flux uncertainties are calculated from the ensembles of prior and optimized surface fluxes assuming Gaussian errors, following previous method used in Peters et al. $(2007,2010)$. The global total biogenic and oceanic optimized $\mathrm{CO}_{2}$ fluxes are similar for the CNTL experiment $\left(-5.54 \pm 1.85 \mathrm{Pg} \mathrm{Cyr}^{-1}\right)$ and JR experiment $\left(-5.55 \pm 1.72 \mathrm{Pg} \mathrm{C} \mathrm{yr}^{-1}\right)$, compared with the global prior flux of $-3.94 \pm 2.24 \mathrm{PgC} \mathrm{yr}^{-1}$. The global land sink in the CNTL experiment is larger by $0.07 \mathrm{Pg} \mathrm{C} \mathrm{yr}^{-1}$ than that of the JR experiment, and the global ocean sink in the CNTL experiment is smaller by $0.08 \mathrm{Pg} \mathrm{C} \mathrm{yr}^{-1}$ than that 
Table 2. A priori and optimized surface $\mathrm{CO}_{2}$ fluxes and their $1 \sigma$ uncertainties $\left(\mathrm{Pg} \mathrm{Cyr}^{-1}\right.$ region $\left.^{-1}\right)$ of global total, land, ocean, and other regions averaged spatially from 2002 to 2009. The CNTL experiment is conducted by using a set of observations without observations in the Siberia region, whereas the JR experiment is conducted using all available observations including the Siberia data.

\begin{tabular}{lrrr}
\hline Region & A priori & CNTL & JR \\
\hline Eurasian boreal & $-0.07 \pm 1.10$ & $-1.17 \pm 0.93$ & $-0.77 \pm 0.70$ \\
Eurasian temperate & $-0.05 \pm 0.49$ & $-0.31 \pm 0.41$ & $-0.36 \pm 0.40$ \\
Europe & $-0.01 \pm 0.76$ & $-0.20 \pm 0.67$ & $-0.37 \pm 0.64$ \\
North American boreal & $-0.04 \pm 0.61$ & $-0.30 \pm 0.38$ & $-0.36 \pm 0.38$ \\
North American temperate & $-0.02 \pm 0.66$ & $-0.55 \pm 0.41$ & $-0.59 \pm 0.41$ \\
Northern Hemisphere total & $-1.42 \pm 1.85$ & $-3.21 \pm 1.49$ & $-3.21 \pm 1.34$ \\
Tropical total & $0.06 \pm 0.80$ & $0.12 \pm 0.74$ & $0.11 \pm 0.74$ \\
Southern Hemisphere total & $-2.57 \pm 0.97$ & $-2.46 \pm 0.81$ & $-2.45 \pm 0.81$ \\
Global total & $-3.94 \pm 2.24$ & $-5.54 \pm 1.85$ & $-5.55 \pm 1.72$ \\
Global land & $-1.33 \pm 1.90$ & $-3.59 \pm 1.57$ & $-3.52 \pm 1.43$ \\
Global ocean & $-2.61 \pm 1.19$ & $-1.95 \pm 0.97$ & $-2.03 \pm 0.96$ \\
\hline
\end{tabular}

of the JR experiment. The additional observations do not introduce any discrepancy between the two experiments with respect to the global total sink, and they indicate only a small difference in the land-ocean $\mathrm{CO}_{2}$ flux partitioning. The estimated $\mathrm{CO}_{2}$ flux uncertainty in the land region from the JR experiment is smaller than that of the CNTL experiment because new observations provide additional constraints on the optimized $\mathrm{CO}_{2}$ flux. For specific regions in the $\mathrm{NH}$, a large difference of optimized surface $\mathrm{CO}_{2}$ flux between the CNTL and JR experiments is observed in the EB. The largest increment between a priori and CNTL is shown in EB where the least in situ observations are available as shown in Fig. 1. The other regions where more local observations are available show smaller increments. The surface $\mathrm{CO}_{2}$ uptake in the $\mathrm{EB}$ of the CNTL experiment is $-1.17 \pm 0.93 \mathrm{PgC}^{-1}$ and that of the JR experiment is $-0.77 \pm 0.70 \mathrm{PgC}^{-1}$, respectively. As expected, the uncertainty of the optimized surface $\mathrm{CO}_{2}$ uptake in the EB in the JR experiment is reduced by assimilating additional observations. In contrast, the surface $\mathrm{CO}_{2}$ uptake increases in other regions of the $\mathrm{NH}$ where no additional observations are assimilated.

Figure 3 presents the spatial distribution of the optimized biosphere fluxes' difference between the CNTL and JR experiments from 2002 to 2009 . The difference of optimized surface $\mathrm{CO}_{2}$ flux is calculated as in Fig. 2b. The largest difference of optimized surface $\mathrm{CO}_{2}$ fluxes between the two experiments occurs in the conifer forest ecoregion of Siberia. Compared to the CNTL experiment, the uptake of optimized surface $\mathrm{CO}_{2}$ flux in Siberia is reduced in JR for all years except 2003. In 2003, extreme drought conditions occurred in all of the northern midlatitudes (Knorr et al., 2007) and Europe (Ciais et al., 2005), which resulted in increased NEE, i.e., reduced uptake of $\mathrm{CO}_{2}$, in $\mathrm{EB}$ in the CNTL experiment. The uptake of optimized surface $\mathrm{CO}_{2}$ fluxes in Siberia in 2003 is reduced in the CNTL experiment due to the remote effect of drought in Europe. Compared to the CNTL experiment, the uptake of optimized surface $\mathrm{CO}_{2}$ fluxes in Siberia in 2003 is not reduced that much in the JR experiment due to the assimilation of the JR-STATION data in Siberia. Despite the number of JR-STATION data used in the optimization in 2003 being relatively smaller than that in the later experiment period, new observations in the JR experiment provide information on the uptake of optimized surface $\mathrm{CO}_{2}$ fluxes in 2003 in Siberia (Fig. 3b).

Optimized surface $\mathrm{CO}_{2}$ fluxes averaged from 2002 to 2009 for each ecoregion in the $\mathrm{NH}$ are shown in Table 3. In Siberia (EB), optimized surface $\mathrm{CO}_{2}$ uptake from the JR experiment is smaller (larger) than that of the CNTL experiment in the conifer forest and northern taiga (in other ecoregions). In the Eurasian temperate (ET), Europe, North American boreal (NAB), and North American temperate (NAT) regions, the optimized surface $\mathrm{CO}_{2}$ uptakes from the JR experiment are larger than those of the CNTL experiment in most ecoregions.

Figure 4 shows the time series of annual and average prior and optimized surface $\mathrm{CO}_{2}$ fluxes over global total, global land, and global ocean. For global total, the magnitude of optimized fluxes is much greater than that of prior fluxes due to the greater uptake of optimized fluxes than that of prior fluxes over global land (Fig. 4a, b). In contrast, the magnitude of optimized fluxes over global ocean is slightly weaker than that of prior fluxes (Fig. 4c). As shown in Table 2, the differences between annual and average optimized surface $\mathrm{CO}_{2}$ fluxes over the globe are small and the average is almost the same for the two experiments (Fig. 4a) with a similar trend of -0.33 and $-0.35 \mathrm{Pg} \mathrm{C} \mathrm{yr}^{-2}$ in the CNTL and JR experiment, respectively, and the differences in global land and ocean are also small (Fig. 4b, c) with a similar trend of $-0.22 \mathrm{Pg} \mathrm{Cyr}^{-2}$ in global land for both the CNTL and JR experiments and -0.11 and $-0.13 \mathrm{Pg} \mathrm{Cyr}^{-2}$ in global ocean for the CNTL and JR experiments, respectively. The optimized surface $\mathrm{CO}_{2}$ fluxes from each experiment show similar interannual variability, which implies that the additional 

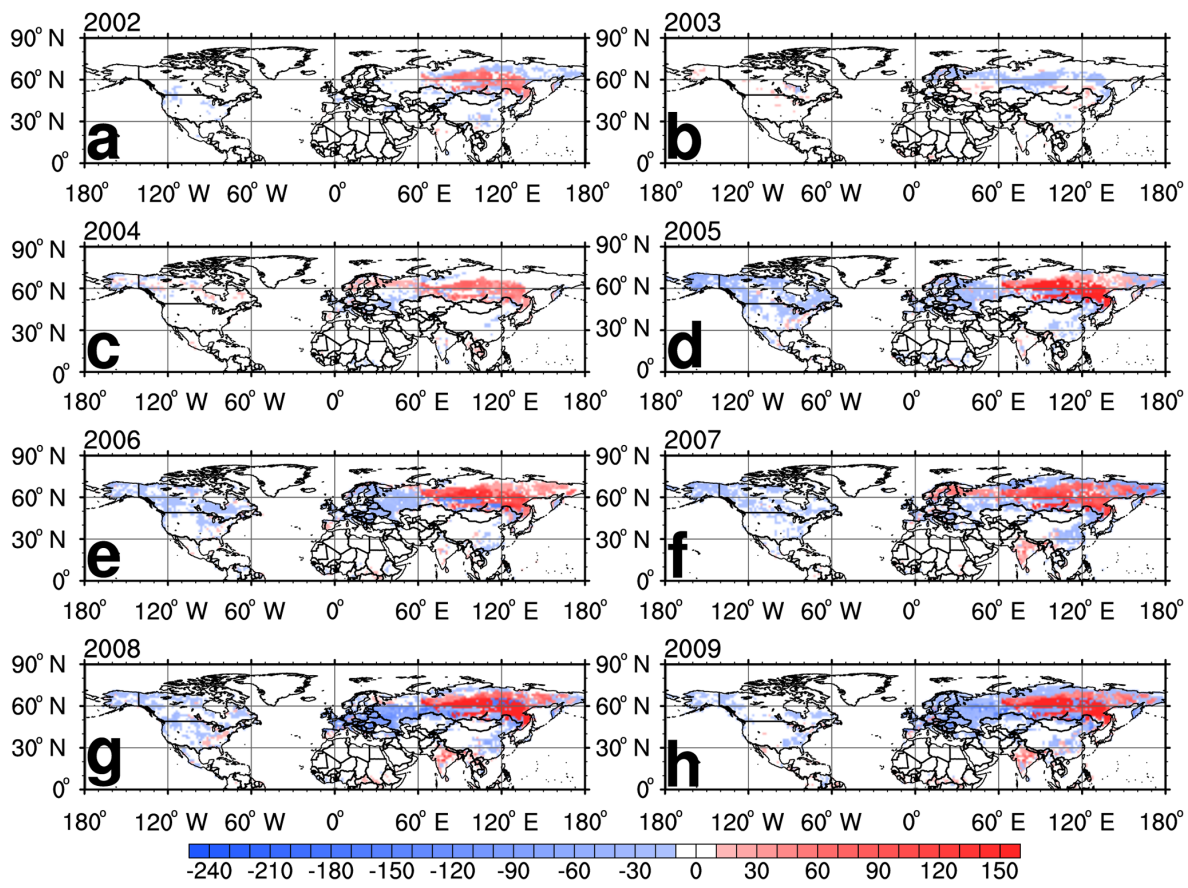

Figure 3. The difference between the optimized biosphere fluxes from the JR and CNTL experiment ( $\left.\mathrm{g} \mathrm{C} \mathrm{m}^{-2} \mathrm{yr}^{-1}\right) \mathrm{of}_{\text {(a) }} 2002$, (b) 2003 , (c) 2004, (d) 2005, (e) 2006, (f) 2007, (g) 2008, and (h) 2009. Blue colors (negative) denote net $\mathrm{CO}_{2}$ flux uptake while red colors (positive) denote net $\mathrm{CO}_{2}$ release to the atmosphere. The difference is calculated by subtracting surface $\mathrm{CO}_{2}$ flux of the CNTL experiment from that of the JR experiment.

Table 3. The optimized surface $\mathrm{CO}_{2}$ fluxes $\left(\mathrm{Pg} \mathrm{C} \mathrm{yr}^{-1}\right.$ region $\left.{ }^{-1}\right)$ of ecosystem types at Eurasian boreal, Eurasian temperate, Europe, North American boreal, and North American temperate region averaged over 2002-2009. The CNTL experiment is conducted by using a set of observations without observations in the Siberia region, whereas the JR experiment is conducted using all available observations including the Siberia data.

\begin{tabular}{lrrrrrrrrrr}
\hline Ecosystem type & \multicolumn{2}{c}{$\begin{array}{c}\text { Eurasian } \\
\text { boreal }\end{array}$} & \multicolumn{2}{c}{$\begin{array}{c}\text { Eurasian } \\
\text { temperate }\end{array}$} & & Europe & \multicolumn{2}{c}{$\begin{array}{c}\text { North American } \\
\text { boreal }\end{array}$} & $\begin{array}{c}\text { North American } \\
\text { temperate }\end{array}$ \\
\cline { 2 - 12 } & CNTL & JR & CNTL & JR & CNTL & JR & CNTL & JR & CNTL & JR \\
\hline Conifer forest & -0.815 & -0.337 & -0.005 & -0.005 & -0.067 & -0.069 & -0.107 & -0.121 & -0.054 & -0.069 \\
Broadleaf forest & -0.006 & -0.013 & -0.004 & -0.005 & -0.005 & -0.005 & 0.000 & 0.000 & -0.002 & -0.002 \\
Mixed forest & -0.049 & -0.090 & -0.029 & -0.034 & -0.025 & -0.063 & -0.053 & -0.054 & -0.019 & -0.021 \\
Grass/shrub & -0.035 & -0.056 & -0.247 & -0.285 & -0.016 & -0.032 & 0.000 & -0.001 & -0.077 & -0.081 \\
Tropical forest & 0.000 & 0.000 & -0.001 & -0.001 & 0.000 & 0.000 & 0.000 & 0.000 & 0.000 & 0.000 \\
Scrub/woods & 0.000 & 0.000 & -0.002 & -0.002 & -0.001 & -0.001 & 0.000 & 0.000 & -0.013 & -0.013 \\
Semitundra & -0.145 & -0.188 & -0.007 & -0.009 & -0.008 & -0.009 & -0.057 & -0.086 & -0.010 & -0.011 \\
Fields/woods/savanna & -0.012 & -0.021 & -0.005 & -0.005 & 0.003 & -0.009 & -0.004 & -0.004 & -0.149 & -0.153 \\
Northern taiga & -0.094 & -0.029 & 0.000 & 0.000 & -0.006 & -0.007 & -0.066 & -0.077 & 0.000 & 0.000 \\
Forest/field & -0.003 & -0.008 & 0.006 & 0.006 & -0.086 & -0.105 & -0.001 & -0.001 & -0.012 & -0.016 \\
Wetland & -0.002 & -0.014 & 0.000 & -0.000 & -0.001 & -0.002 & -0.003 & -0.006 & -0.002 & -0.003 \\
Shrub/tree/suc* & 0.000 & 0.000 & -0.001 & -0.001 & 0.000 & 0.000 & 0.000 & 0.000 & 0.000 & 0.000 \\
Crops & -0.002 & -0.008 & -0.019 & -0.022 & -0.007 & -0.075 & 0.000 & 0.000 & -0.216 & -0.227 \\
Wooded tundra & -0.003 & -0.005 & 0.000 & 0.000 & 0.003 & 0.003 & -0.003 & -0.002 & 0.000 & 0.000 \\
Water & 0.000 & 0.000 & 0.000 & 0.000 & 0.000 & 0.000 & -0.001 & -0.001 & -0.001 & -0.001 \\
\hline
\end{tabular}

* "Suc" indicates succulents and thorn scrubs.

Siberian observations do not affect the interannual variability of global surface $\mathrm{CO}_{2}$ uptake.
Figure 5 is the same as Fig. 4 but covers land regions in the $\mathrm{NH}$. Although the optimized surface $\mathrm{CO}_{2}$ fluxes over global 

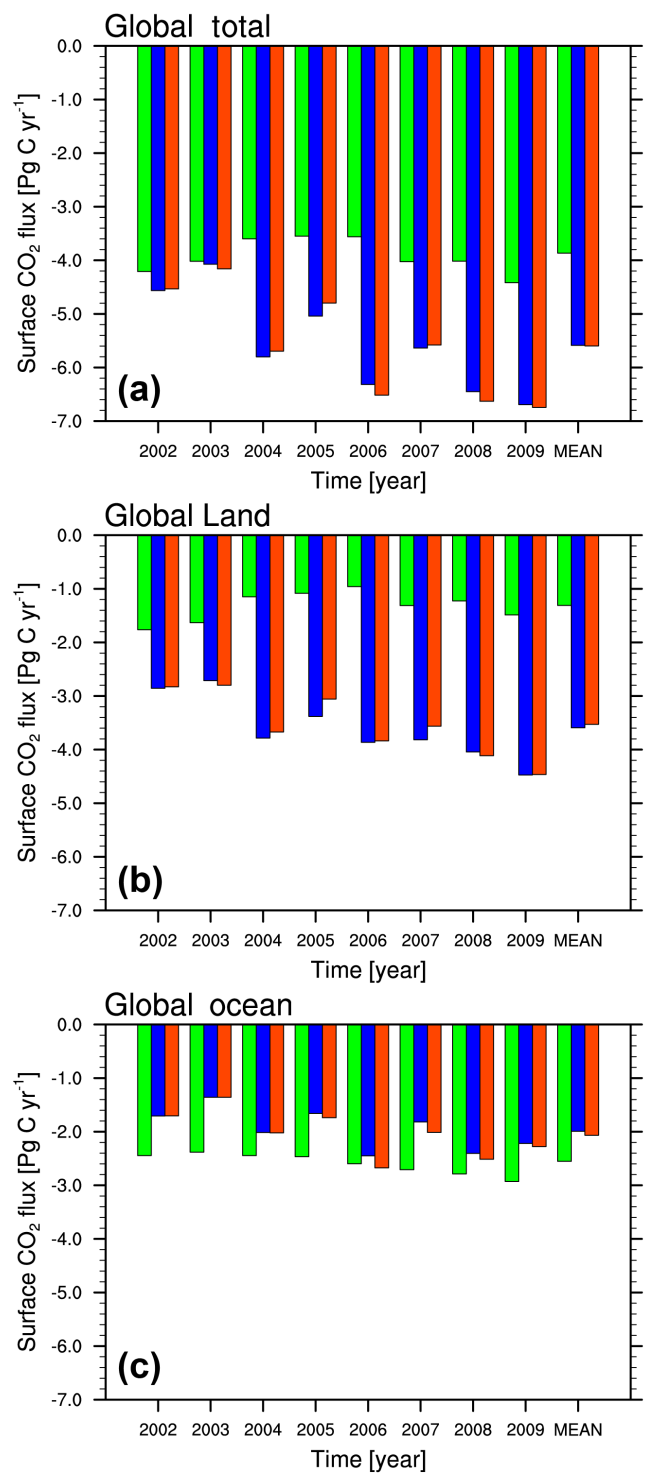

Figure 4. Annual and average biosphere and ocean fluxes $\left(\mathrm{PgC} \mathrm{yr}^{-1}\right.$ ) from the prior (green bar), CNTL (blue bar), and JR (red bar) experiment aggregated over the (a) whole globe, (b) land, and (c) ocean.

total are similar, those over each Transcom region are different in each experiment. The optimized fluxes over each region show greater annual uptake relative to the prior fluxes in both experiment. As expected, the difference between the two experiments is largest in the EB (Fig. 5a) where the new additional observations are assimilated. The JR experiment exhibits a weaker surface $\mathrm{CO}_{2}$ uptake in the EB than does the CNTL experiment except for 2003 as shown in Fig. 3b, whereas the JR experiment exhibits a greater surface $\mathrm{CO}_{2}$ uptake in the other regions, especially over Europe in 2008 and 2009, than the CNTL experiment (Fig. 5b-e). It is driven by the increase of $\mathrm{CO}_{2}$ uptake in eastern Europe (Fig. 3g, h). Because most of JR-STATION sites are

located in the western part of Siberia (Fig. 1), the optimized surface $\mathrm{CO}_{2}$ fluxes over eastern Europe could be affected by JR-STATION observations. The trend of EB in the CNTL experiment is $-0.06 \mathrm{Pg} \mathrm{C} \mathrm{yr}^{-2}$, whereas that in the JR experiment is $0.02 \mathrm{Pg} \mathrm{C} \mathrm{yr}^{-2}$ due to the reduced uptake of $\mathrm{CO}_{2}$ in the JR experiment since 2005 (Fig. 5a). As a result, the trends of the surface $\mathrm{CO}_{2}$ uptake of $\mathrm{EB}$ and Europe in the two experiments show opposite signs. In contrast, the surface $\mathrm{CO}_{2}$ uptake trends of other land regions in the $\mathrm{NH}$ are similar between the two experiments.

Figure 6 shows monthly prior and optimized surface $\mathrm{CO}_{2}$ fluxes averaged from 2002 to 2009 with their uncertainties from both experiments. In general, optimized fluxes in both experiments show greater uptake in boreal summer and weaker uptake in other seasons compared to the prior fluxes, which results in greater annual $\mathrm{CO}_{2}$ uptake of optimized fluxes than prior fluxes as shown in Fig. 5. The largest difference in surface $\mathrm{CO}_{2}$ flux between the two experiments occurs in June and July, which represent the active season of the terrestrial ecosystem with a large surface $\mathrm{CO}_{2}$ flux uncertainty. The JR experiment exhibits a weaker surface $\mathrm{CO}_{2}$ summer uptake in the EB (Fig. 6a) and slightly greater uptake in the other regions (Fig. 6b-e). These additional JRSTATION data provides information on the surface $\mathrm{CO}_{2}$ uptake by vegetation activities in the $\mathrm{NH}$ summer.

\subsection{Comparison with observations}

Table 4 presents the average bias of the model $\mathrm{CO}_{2}$ concentrations calculated by the background and optimized fluxes of the two experiments at each observation site located in Asia and Europe from 2002 to 2009. The bias is calculated by subtracting the observed $\mathrm{CO}_{2}$ concentrations from the model $\mathrm{CO}_{2}$ concentrations. Biases of the JR experiment are smaller than those of the CNTL experiment at the JR-STATION sites, which indicates that the optimized surface $\mathrm{CO}_{2}$ flux of the $\mathrm{JR}$ experiment is more consistent with the observed $\mathrm{CO}_{2}$ concentrations than that in the CNTL experiment. The negative bias at five JR-STATION sites (DEM, IGR, KRS, NOY, and YAK shown in Fig. 1 and Table 1) located in the forest area of the EB is reduced compared with those of the CNTL experiment, which indicates that the optimized surface $\mathrm{CO}_{2}$ uptake of the CNTL experiment is overestimated with respect to $\mathrm{CO}_{2}$ concentration observations in Siberia. Otherwise, the reduced surface $\mathrm{CO}_{2}$ uptake of the JR experiment exhibits more consistent model $\mathrm{CO}_{2}$ concentrations in this region. In addition to the average bias for the entire period, the time series of monthly averaged bias of the model $\mathrm{CO}_{2}$ concentrations from the observed $\mathrm{CO}_{2}$ concentrations at the JR-STATION sites shows that the JR experiment consistently shows smaller biases compared to the CNTL experiment (not shown), which implies that the model representation of $\mathrm{CO}_{2}$ at JR-STATION sites is more accurate in the JR experiment than in the CNTL experiment. Model $\mathrm{CO}_{2}$ concentrations calculated by background surface $\mathrm{CO}_{2}$ fluxes in

Atmos. Chem. Phys., 17, 2881-2899, 2017 

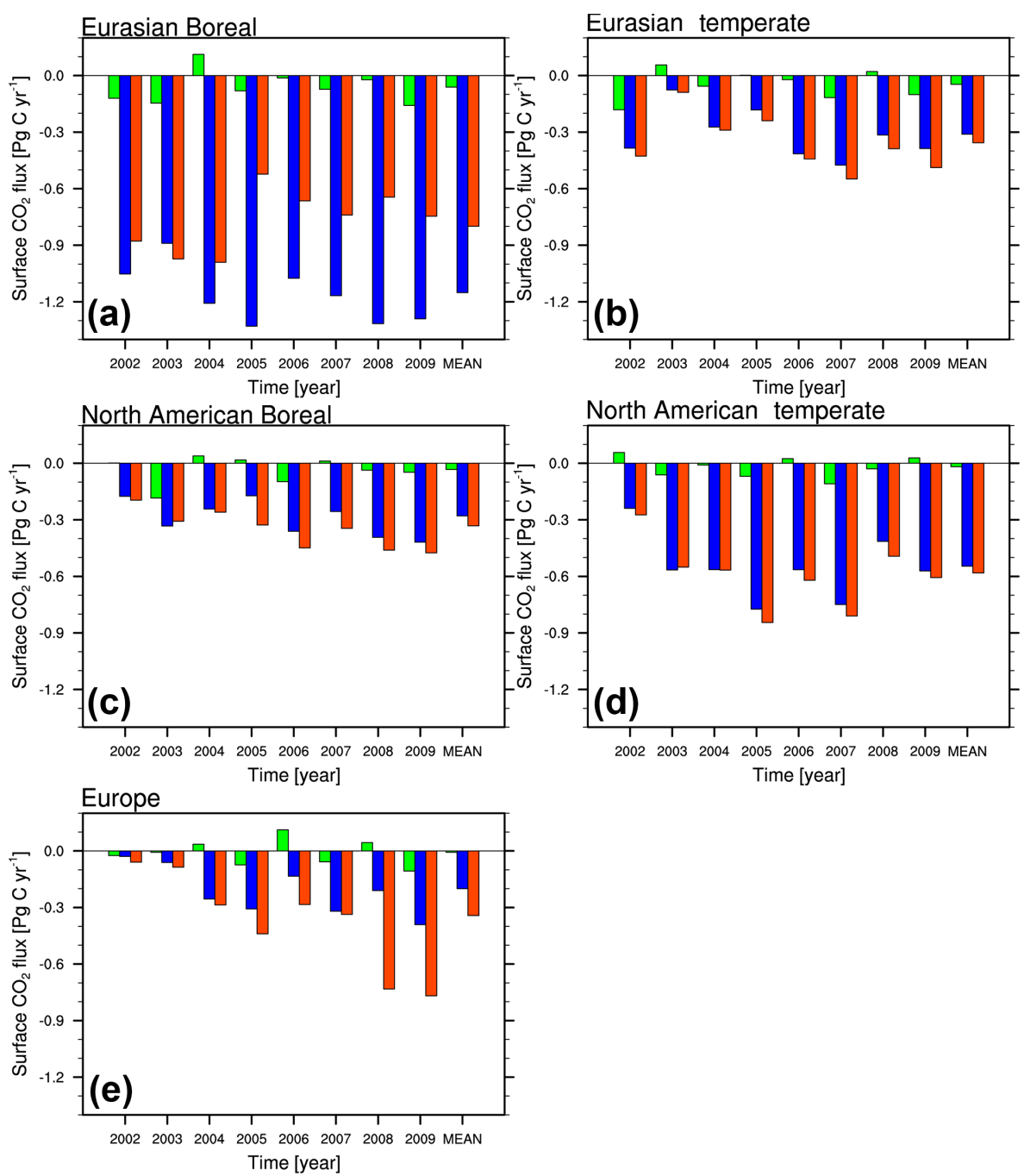

Figure 5. Annual and average biosphere fluxes $\left(\mathrm{PgC} \mathrm{yr}^{-1}\right.$ ) from the prior (green bar), CNTL (blue bar), and JR (red bar) experiment aggregated over the (a) Eurasian boreal, (b) Eurasian temperate, (c) North American boreal, (d) North American temperate, and (e) Europe.

the JR experiment are also more consistent with the observations, implying that background scaling factors of the JR experiment are more accurate than those of the CNTL experiment. The background surface $\mathrm{CO}_{2}$ fluxes are calculated by multiplying the background scaling factor with prior biosphere and ocean fluxes as in Eq. (1). In addition, the average innovation $\chi^{2}$ statistics at the JR-STATION sites are generally close to 1 , implying that the defined MDM is an appropriate value. Therefore, by assimilating JR-STATION observation data, the JR experiment exhibits better results than the CNTL experiment at observation sites in EB.

However, at observation sites in ET and Europe, the difference in biases of the two experiments is relatively small and not significant enough to determine which experiment exhibits better results. This is due to the small difference of optimized surface $\mathrm{CO}_{2}$ fluxes between the two experiments in the ET region. The observation sites in Europe are located far from eastern Europe and Siberia, as shown in Fig. 1, so that they are not sensitive to the change of surface $\mathrm{CO}_{2}$ uptake in those regions. In addition, the MDM at four sites (BAL, BSC, HUN, and OBN) in Europe is assigned as $7.5 \mathrm{ppm}$, the largest value in CarbonTracker, due to poor representation of the transport model at these sites (Peters et al., 2010).

In addition, model $\mathrm{CO}_{2}$ concentrations calculated by optimized fluxes of the two experiments are compared with independent, not assimilated, vertical profiles of $\mathrm{CO}_{2}$ concentration measurements by aircraft at the BRZ site in Siberia. Aircraft measurements were conducted in the afternoon on good weather days. The frequency of flight was usually two to four times per month (Sasakawa et el., 2013). Table 5 presents the average bias, root mean square difference (RMSD), mean absolute error (MAE), and Pearson's correlation coefficient of the model $\mathrm{CO}_{2}$ concentrations calculated by optimized fluxes of the two experiments based on the observations at BRZ site 

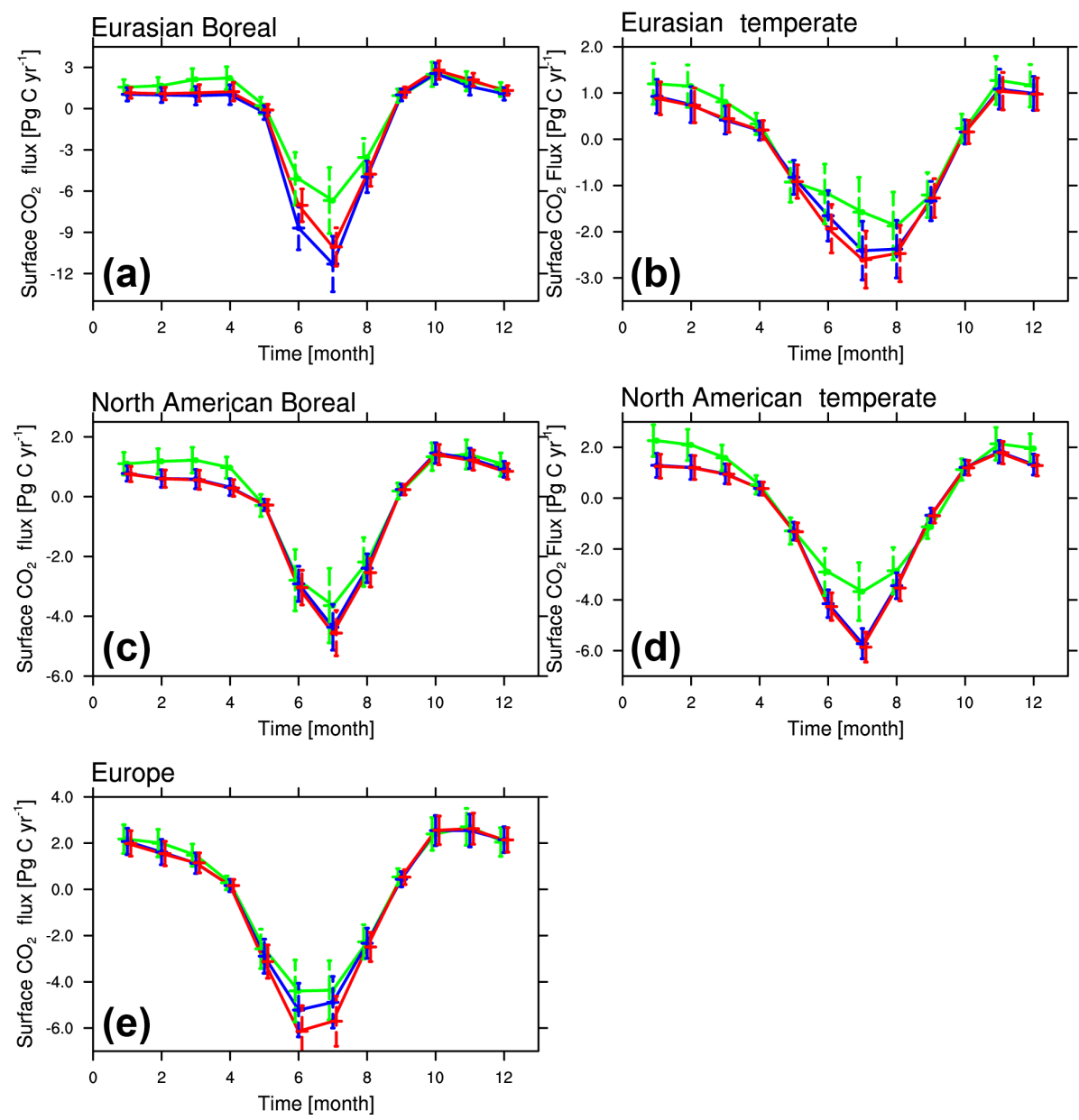

Figure 6. The monthly prior (green) and optimized biosphere fluxes averaged from 2002 to 2009 of the CNTL (blue) and JR (red) experiments with their uncertainties over the (a) Eurasian boreal, (b) Eurasian temperate, (c) North American boreal, (d) North American temperate, and (e) Europe.

as the reference. The statistics are calculated at each vertical bin at $500 \mathrm{~m}$ intervals by using aircraft measurements observed between 12:00 and 16:00 LST. Overall, the biases of the two experiments are less than $0.80 \mathrm{ppm}$, showing good consistency between model and observed $\mathrm{CO}_{2}$ concentrations. Near the surface, the result of the JR experiment is better than that of CNTL experiment in terms of bias. The bias of the JR experiment is smaller than that of the CNTL experiment at the level under $500 \mathrm{~m}$, whereas the biases of the CNTL experiment are smaller than those of the JR experiment at the levels above $500 \mathrm{~m}$. More $\mathrm{CO}_{2}$ concentrations are generated over the BRZ site because of the reduced uptake of surface $\mathrm{CO}_{2}$ fluxes over Siberia in the JR experiment. The standard deviations of the CNTL experiment are greater than those of the JR experiment, which implies that the biases of the CNTL experiment fluctuate about its average more than those of the JR experiment. In contrast, the RMSD and MAE of the JR experiment are smaller than those of the CNTL experiment, and the correlation coefficient of the JR experiment is greater than that of the CNTL experiment. Therefore, overall, the statistics show that the model $\mathrm{CO}_{2}$ concentrations of the JR experiment are relatively more consistent with independent $\mathrm{CO}_{2}$ concentration observations compared to those of the CNTL experiment over Siberia.

\subsection{Uncertainty reduction and observation impact}

The effects of additional observations on the optimized surface $\mathrm{CO}_{2}$ flux and associated uncertainties are investigated. Figure 7 shows the average uncertainty reduction from 2002 to 2009: the average in summer (June, July, and August) and average in winter (December, January, February). The uncertainty reduction based on the uncertainty of CNTL as the reference is calculated as

$U R=\frac{\sigma_{\mathrm{CNTL}}-\sigma_{\mathrm{JR}}}{\sigma_{\mathrm{CNTL}}} \times 100(\%)$,

where $\sigma_{\mathrm{CNTL}}$ and $\sigma_{\mathrm{JR}}$ are $1 \sigma$ standard deviations of the optimized scaling factor for the CNTL experiment and JR ex- 
Table 4. Average differences between model $\mathrm{CO}_{2}$ concentrations (ppm) simulated using the background and the observed $\mathrm{CO}_{2}$ concentration (ppm) (fourth and sixth columns), model $\mathrm{CO}_{2}$ concentrations (ppm) simulated using the optimized surface $\mathrm{CO}_{2}$ flux and the observed $\mathrm{CO}_{2}$ concentration (ppm) (fifth and seventh columns), and average innovation $\chi^{2}$ from 2002 to 2009 at observation sites located in Asia and Europe (eighth column). The CNTL experiment is conducted by using a set of observations without observations in the Siberia region, whereas the JR experiment is conducted using all available observations including the Siberia data.

\begin{tabular}{|c|c|c|c|c|c|c|c|}
\hline \multirow[t]{2}{*}{ Region } & \multirow[t]{2}{*}{ Site } & \multirow{2}{*}{$\begin{array}{l}\text { MDM } \\
(\mathrm{ppm})\end{array}$} & \multicolumn{2}{|c|}{ CNTL } & \multicolumn{2}{|c|}{$\mathrm{JR}$} & \multirow[b]{2}{*}{$\begin{array}{r}\text { Innovation } \\
\chi^{2}\end{array}$} \\
\hline & & & $\begin{array}{r}\text { Bias } \\
\text { (background) }\end{array}$ & $\begin{array}{r}\text { Bias } \\
\text { (optimized) }\end{array}$ & $\begin{array}{r}\text { Bias } \\
\text { (background) }\end{array}$ & $\begin{array}{r}\text { Bias } \\
\text { (optimized) }\end{array}$ & \\
\hline \multirow{9}{*}{$\begin{array}{l}\text { Eurasian } \\
\text { boreal }\end{array}$} & AZV & 3 & 1.68 & 1.04 & 0.77 & 0.19 & 0.85 \\
\hline & $\mathrm{BRZ}$ & 3 & 1.41 & 0.68 & 0.67 & 0.39 & 1.17 \\
\hline & DEM & 3 & 0.15 & -0.84 & 0.32 & 0.11 & 0.84 \\
\hline & IGR & 3 & -1.58 & -2.71 & -0.52 & -1.26 & 1.15 \\
\hline & KRS & 3 & 0.57 & -0.22 & 0.27 & 0.12 & 1.22 \\
\hline & NOY & 3 & -0.02 & -1.06 & 0.16 & 0.00 & 0.86 \\
\hline & SVV & 3 & 1.25 & 0.71 & 0.63 & 0.09 & 0.96 \\
\hline & VGN & 3 & 2.55 & 2.11 & 1.50 & 0.84 & 1.18 \\
\hline & YAK & 3 & 0.23 & -2.18 & 0.87 & 0.03 & 1.36 \\
\hline \multirow{14}{*}{$\begin{array}{l}\text { Eurasian } \\
\text { temperate }\end{array}$} & WLG & 1.5 & 0.17 & 0.19 & 0.15 & 0.16 & 1.09 \\
\hline & BKT & 7.5 & 4.12 & 4.06 & 4.13 & 4.05 & 0.57 \\
\hline & WIS & 2.5 & 0.27 & 0.12 & 0.22 & 0.07 & 0.72 \\
\hline & KZD & 2.5 & 1.79 & 0.98 & 1.42 & 1.14 & 1.26 \\
\hline & KZM & 2.5 & 1.17 & 0.96 & 1.13 & 0.93 & 1.26 \\
\hline & TAP & 5 & 0.50 & 0.55 & 0.58 & 0.71 & 0.58 \\
\hline & UUM & 2.5 & 0.24 & -0.07 & 0.20 & 0.12 & 1.05 \\
\hline & CRI & 3 & -1.95 & -1.57 & -1.94 & -1.56 & 0.66 \\
\hline & LLN & 7.5 & 4.42 & 3.09 & 4.42 & 3.09 & 0.47 \\
\hline & SDZ & 3 & -3.02 & -5.26 & -3.09 & -5.28 & 2.08 \\
\hline & MNM & 3 & 0.56 & 0.52 & 0.59 & 0.56 & 0.17 \\
\hline & RYO & 3 & 1.26 & 1.16 & 1.32 & 1.32 & 1.07 \\
\hline & YON & 3 & 1.10 & 0.98 & 1.14 & 1.07 & 0.56 \\
\hline & GSN & 3 & -1.92 & -1.71 & -1.92 & -1.70 & 1.83 \\
\hline \multirow[t]{7}{*}{ Europe } & BAL & 7.5 & -1.23 & -1.32 & -1.31 & -1.45 & 0.37 \\
\hline & BSC & 7.5 & -4.12 & -4.97 & -4.12 & -5.13 & 1.01 \\
\hline & HUN & 7.5 & 0.93 & 0.53 & 0.86 & 0.36 & 0.46 \\
\hline & OBN & 7.5 & 0.70 & -0.71 & 0.59 & -0.89 & 0.44 \\
\hline & OXK & 2.5 & 0.50 & 0.02 & 0.43 & -0.09 & 1.52 \\
\hline & PAL & 2.5 & 0.47 & 0.07 & 0.58 & 0.16 & 0.76 \\
\hline & STM & 1.5 & 0.54 & 0.42 & 0.55 & 0.42 & 0.76 \\
\hline
\end{tabular}

Table 5. Bias, root mean square difference, mean absolute error, and Pearson's correlation coefficient of the model $\mathrm{CO}_{2}$ concentration of CNTL and JR experiments in comparison with the vertical profile of $\mathrm{CO}_{2}$ concentrations at the BRZ site.

\begin{tabular}{|c|c|c|c|c|c|c|c|c|}
\hline \multirow[t]{2}{*}{$\begin{array}{l}\text { Altitude } \\
(\mathrm{km})\end{array}$} & \multicolumn{2}{|c|}{ Bias (ppm) } & \multicolumn{2}{|c|}{$\begin{array}{c}\text { Root mean } \\
\text { square } \\
\text { difference }(\mathrm{ppm})\end{array}$} & \multicolumn{2}{|c|}{$\begin{array}{c}\text { Mean } \\
\text { absolute } \\
\text { error }(\mathrm{ppm})\end{array}$} & \multicolumn{2}{|c|}{$\begin{array}{l}\text { Pearson's } \\
\text { correlation } \\
\text { coefficient }\end{array}$} \\
\hline & CNTL & JR & CNTL & JR & CNTL & JR & CNTL & JR \\
\hline$<0.5$ & $-0.38 \pm 4.73$ & $-0.05 \pm 4.39$ & 4.06 & 3.75 & 3.42 & 3.07 & 0.94 & 0.95 \\
\hline $0.5-1.0$ & $0.23 \pm 4.05$ & $0.42 \pm 3.75$ & 3.58 & 3.33 & 2.94 & 2.72 & 0.94 & 0.95 \\
\hline $1.0-1.5$ & $0.19 \pm 3.80$ & $0.31 \pm 3.53$ & 3.35 & 3.11 & 2.70 & 2.49 & 0.94 & 0.95 \\
\hline $1.5-2.0$ & $0.22 \pm 3.38$ & $0.33 \pm 3.19$ & 2.94 & 2.79 & 2.33 & 2.19 & 0.93 & 0.94 \\
\hline $2.0-2.5$ & $0.02 \pm 3.19$ & $0.08 \pm 3.07$ & 2.64 & 2.54 & 2.19 & 2.11 & 0.93 & 0.94 \\
\hline $2.5-3.0$ & $0.79 \pm 2.84$ & $0.80 \pm 2.53$ & 1.44 & 1.30 & 2.21 & 1.99 & 0.92 & 0.94 \\
\hline$>3.0$ & $0.61 \pm 3.15$ & $0.61 \pm 2.91$ & 1.49 & 1.38 & 2.42 & 2.26 & 0.89 & 0.91 \\
\hline
\end{tabular}



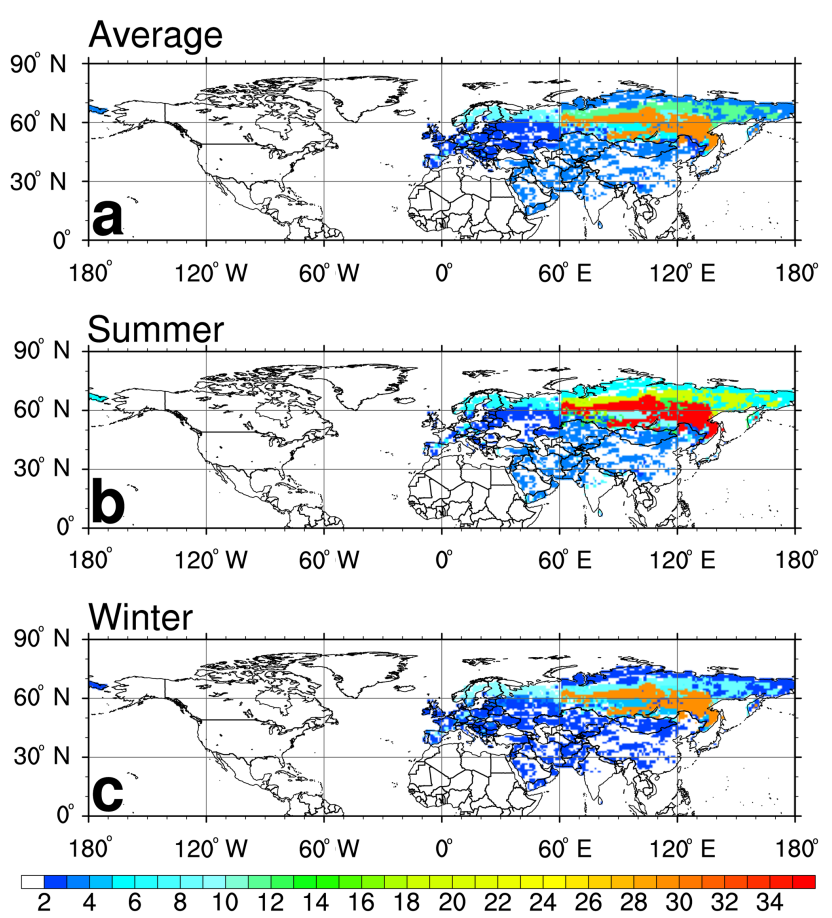

Figure 7. (a) Average uncertainty reduction (\%) from 2002 to 2009 , average uncertainty reduction $(\%)$ in (b) summer, and in (c) winter for the estimated uncertainty of the JR experiment relative to that of the CNTL experiment. Red (blue) denotes relatively high (low) values of uncertainty reduction.

periment, respectively. The maximum uncertainty reduction is the greatest value in any week in the period 2002 to 2009 in each ecoregion. As expected, the average uncertainty reduction is apparent in the conifer forest of EB in which JR stations are mainly located, which has the additional observations (Fig. 7a). The uncertainty reduction in Asia and Europe, especially in the forests of Siberia and eastern Europe, is greater than for other regions. The spatial pattern of the maximum uncertainty reduction is similar to that of the average values from 2002 to 2009 (not shown). The uncertainty reduction of EB in summer is higher than that in winter (Fig. 7b, c) due to a higher uncertainty associated with larger net fluxes in summer compared to winter (Fig. 6a). For example, the average value of the conifer forest of EB is $29.1 \%$, the maximum value is $78.6 \%$, the average value in summer is $36.3 \%$, and the average value in winter is $29.7 \%$, respectively. The uncertainty reduction of the CNTL and JR experiments based on the prior uncertainty as the reference ( $\sigma_{\text {prior }}$ used instead of $\sigma_{\mathrm{CNTL}}$ in Eq. 8 ; $\sigma_{\mathrm{CNTL}}$ or $\sigma_{\mathrm{JR}}$ used instead of $\sigma_{\mathrm{JR}}$ in Eq. 8) shows similar values in the NH except in the Siberia region (not shown). In addition, the difference between average uncertainty reduction of the CNTL and JR experiments based on the prior uncertainty as the reference (not shown) is very similar to the average of the uncertainty reduction in Eq. (8) shown in Fig. 7a. Therefore, the uncer-

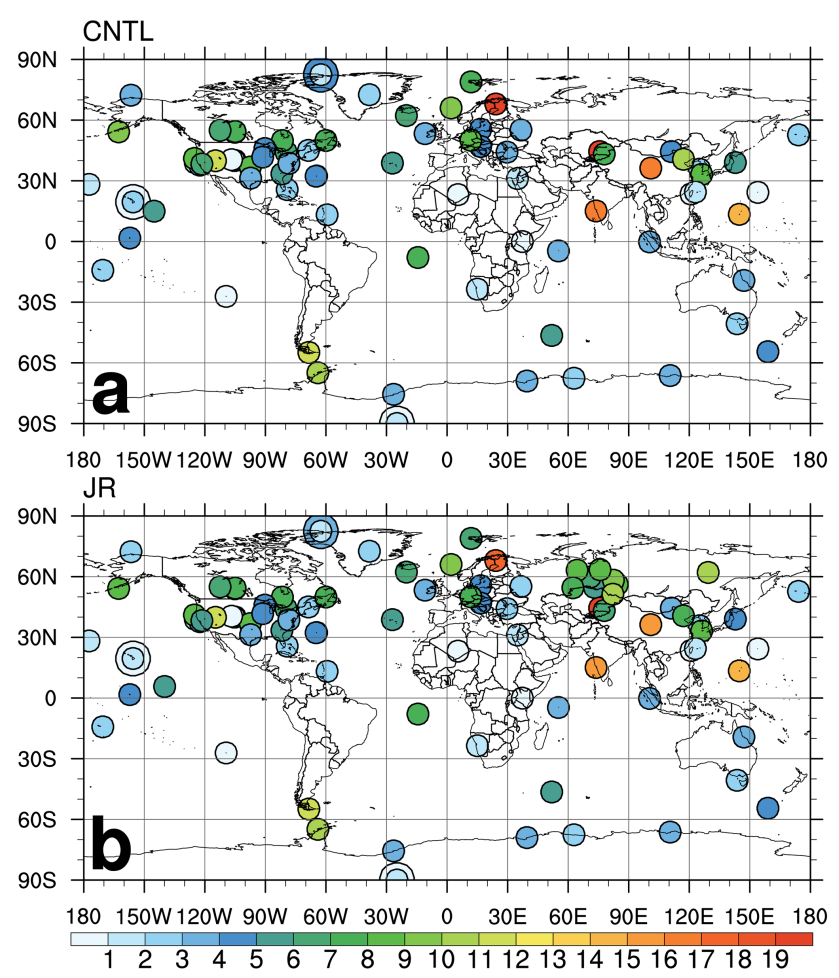

Figure 8. Self-sensitivity at each observation site averaged from 2002 to 2009 of the (a) CNTL experiment and the (b) JR experiment. The overlapping observation sites at the same locations or at close locations are distinguished by different sizes of circles. Red (blue) denotes relatively high (low) values of self-sensitivity.

tainties of the optimized surface $\mathrm{CO}_{2}$ fluxes are reduced by the additional observations.

To investigate the impact of individual observations on the optimized surface $\mathrm{CO}_{2}$ fluxes, the self-sensitivities are calculated by the method demonstrated by Kim et al. (2014b). The self-sensitivity is the diagonal element of the influence matrix which measures the impact of individual observations in the observation space on the optimized surface $\mathrm{CO}_{2}$ flux. A large self-sensitivity value implies that the information extracted from observations is large. Figure 8 shows the selfsensitivities of the two experiments averaged from 2002 to 2009. The average self-sensitivities at the JR-STATION sites are approximately $60 \%$ larger than those at the towers in North America, i.e., continuous site category observations in Fig. 1. The global average self-sensitivities are $4.83 \%$ (CNTL experiment) and $5.08 \%$ (JR experiment), and the cumulative impacts for the 5-week assimilation window are $18.79 \%$ (CNTL experiment) and $19.33 \%$ (JR experiment). The average self-sensitivities of additional observations are higher than those of other sites, providing more information for estimating surface $\mathrm{CO}_{2}$ fluxes. In particular, the YAK site located in east Siberia provides greater impacts than other JR-STATION sites located at $60-90^{\circ} \mathrm{E}$. 


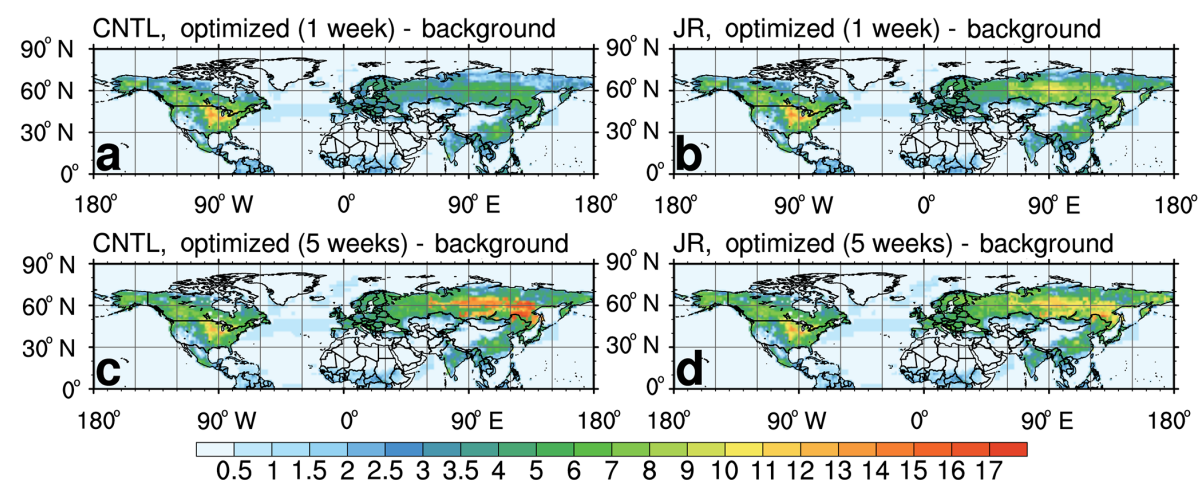

Figure 9. RMSD averaged from 2002 to 2009 between the background flux and posterior flux optimized in Northern Hemisphere summer by 1 week of observations of the (a) CNTL and the (b) JR experiment and by 5 weeks of observations of (c) CNTL and (d) JR experiment. The units are $\mathrm{g} \mathrm{C} \mathrm{m}^{-2}$ week $^{-1}$. Red (blue) denotes a relatively high (low) value of RMSD.

The RMSDs between the optimized surface $\mathrm{CO}_{2}$ fluxes and the background fluxes at each assimilation step in summer are calculated (Fig. 9). The RMSD of the analyzed surface $\mathrm{CO}_{2}$ fluxes constrained by 1 week of observations from the background fluxes in the JR experiment is greater than that in CNTL experiment (Fig. 9a, b), implying that surface $\mathrm{CO}_{2}$ fluxes in Siberia are analyzed by JR-STATION data in Siberia directly at the first assimilation step. This is consistent with the high value of self-sensitivities at JRSTATION sites as shown in Fig. 8b. Because JR-STATION data are abundant and have large self-sensitivities, these observations provide significant information on the estimated surface $\mathrm{CO}_{2}$ fluxes over Siberia in the first cycle. Kim et al. (2014b) showed that the RMSD in Asia increases after 5 weeks of optimization, which implies that it takes more than 1 week to affect the surface $\mathrm{CO}_{2}$ fluxes in Siberia by the transport of the $\mathrm{CO}_{2}$ concentrations observed in remote regions. However, by assimilating the $\mathrm{CO}_{2}$ concentrations observed at the JR-STATION sites in Siberia, the observation impact on the optimized surface $\mathrm{CO}_{2}$ fluxes in Siberia increases after 1 week of optimization (Fig. 9b). In contrast, the RMSD in the Siberia region increases after 5 weeks of optimization in the CNTL experiment compared to that in the JR experiment (Fig. 9c, d), which corresponds to the reduced uptake of optimized surface $\mathrm{CO}_{2}$ fluxes in JR experiment as shown in Fig. $2 b$.

\subsection{Comparison with other results}

A comparison of the optimized surface $\mathrm{CO}_{2}$ flux in this study with other previous studies is presented in Table 6 . In the $\mathrm{EB}$, the land sink from the JR experiment $\left(-0.77 \pm 0.70 \mathrm{PgC} \mathrm{yr}^{-1}\right)$ is smaller than that reported by Zhang et al. (2014b) $\left(-1.02 \pm 0.91 \mathrm{PgC} \mathrm{yr}^{-1}\right)$, Maki et al. (2010) $\left(-1.46 \pm 0.41 \mathrm{PgC} \mathrm{yr}^{-1}\right)$, and the CT2013B (CarbonTracker released on 9 February 2015; documented online at http://www.esrl.noaa.gov/gmd/ccgg/ carbontracker/CT2013B/) results $\left(-1.00 \pm 3.75 \mathrm{Pg} \mathrm{C} \mathrm{yr}^{-1}\right)$, but higher than those reported by Saeki et al. (2013) $\left(-0.35 \pm 0.61 \mathrm{PgC} \mathrm{yr}^{-1} ; \quad\right.$ including biomass burning $\left.0.11 \mathrm{PgC} \mathrm{yr}^{-1}\right)$, and similar to those reported by Dolman et al. (2012) $\left(-0.613 \mathrm{Pg} \mathrm{C} \mathrm{yr}^{-1}\right)$.

Because CT2013B and Zhang et al. (2014b) use an inversion framework similar to that in this study, the reduced land sink is caused by assimilating additional observations. The difference in the land sink between the JR experiment and Saeki et al. (2013) is caused by a different inversion system framework (i.e., prior flux information, atmospheric transport model, observation data set, and inversion method) between two studies. Despite the different inversion system framework used in each study, the two studies using the JRSTATION data exhibit similar results in relative terms, reduced uptake of $\mathrm{CO}_{2}$ fluxes, and uncertainties over Siberia. Nevertheless, the land sink from the JR experiment is somewhat different from other inversion results, as its value falls within the flux uncertainty range. Although the land sink in Dolman et al. (2012) is the average land sink obtained from three methods (inventory-based, eddy covariance, and inversion methods) and estimated not only for Siberia but for territories of Russia, Ukraine, Belarus, and Kazakhstan, the land sinks of the JR experiment and Dolman et al. (2012) show similar values. Overall, the optimized surface $\mathrm{CO}_{2}$ fluxes in EB of the JR experiment are comparable to those of the studies mentioned above.

In Europe, though the long-term average land sink from the JR experiment $\left(-0.37 \pm 0.64 \mathrm{PgC} \mathrm{yr}^{-1}\right)$ is higher in magnitude than that of CTE2014 $\left(-0.07 \pm 0.49 \mathrm{Pg} \mathrm{C} \mathrm{yr}^{-1}\right)$, the average land sink from 2008 to 2009 of the JR experiment $\left(-0.75 \pm 0.63 \mathrm{Pg} \mathrm{C} \mathrm{yr}^{-1}\right)$ is much higher in magnitude than that of CTE2014 $\left(-0.11 \pm 0.38 \mathrm{Pg} \mathrm{C} \mathrm{yr}^{-1}\right)$. The land sinks of the JR experiment in 2008 and 2009 are $-0.73 \pm 0.41$ and $-0.76 \pm 0.38 \mathrm{PgC} \mathrm{yr}^{-1}$, respectively, whereas much lower uptakes $\left(-0.21 \pm 0.49,-0.38 \pm 0.44 \mathrm{Pg} \mathrm{Cyr}^{-1}\right)$ are obtained for the CNTL experiment. According to Reuter et al. (2014), despite the different experiment period, the land 
Table 6. Optimized surface $\mathrm{CO}_{2}$ fluxes $\left(\mathrm{Pg} \mathrm{C} \mathrm{yr}^{-1}\right)$ from this study and other inversion studies.

\begin{tabular}{|c|c|c|c|c|}
\hline Citation & Area & $\begin{array}{r}\text { Estimate surface } \\
\mathrm{CO}_{2} \text { flux }\end{array}$ & Period & Remarks \\
\hline This study & $\begin{array}{l}\text { Eurasian } \\
\text { boreal }\end{array}$ & $-0.77 \pm 0.70$ & 2002-2009 & JR experiment \\
\hline Saeki et al. (2013) & $\begin{array}{l}\text { Eurasian } \\
\text { boreal }\end{array}$ & $-0.35 \pm 0.61$ & 2000-2009 & $\begin{array}{l}\text { Including biomass } \\
\text { burning }\left(0.11 \mathrm{Pg} \mathrm{C} \mathrm{yr}^{-1}\right) \text {, } \\
\text { Using JR-STATION } \\
\text { observations }\end{array}$ \\
\hline Zhang et al. (2014b) & $\begin{array}{l}\text { Eurasian } \\
\text { boreal }\end{array}$ & $-1.02 \pm 0.91$ & 2006-2010 & $\begin{array}{l}\text { Using CONTRAIL } \\
\text { observations }\end{array}$ \\
\hline Maki et al. (2010) & $\begin{array}{l}\text { Eurasian } \\
\text { boreal }\end{array}$ & $-1.46 \pm 0.41$ & 2001-2007 & \\
\hline Dolman et al. (2012) & Russia $^{a}$ & -0.613 & & $\begin{array}{l}\text { Average of inventory- } \\
\text { based, eddy covariance, } \\
\text { and inversion methods }\end{array}$ \\
\hline CT2013B ${ }^{b}$ & $\begin{array}{l}\text { Eurasian } \\
\text { boreal }\end{array}$ & $-1.00 \pm 3.75$ & 2002-2009 & \\
\hline This study & Europe & $\begin{array}{l}-0.38 \pm 0.64 \\
-0.75 \pm 0.63\end{array}$ & $\begin{array}{l}2002-2009 \\
2008-2009\end{array}$ & JR experiment \\
\hline $\begin{array}{l}\text { Reuter et al. (2014) } \\
\text { CTE2014 }^{\text {c }}\end{array}$ & $\begin{array}{l}\text { Europe } \\
\text { Europe }\end{array}$ & $\begin{array}{l}-1.02 \pm 0.30 \\
-0.07 \pm 0.49 \\
-0.11 \pm 0.38\end{array}$ & $\begin{array}{c}2010 \\
2002-2009 \\
2008-2009\end{array}$ & Using satellite data \\
\hline
\end{tabular}

a Including Ukraine, Belarus, and Kazakhstan (total area is $17.1 \times 10^{12} \mathrm{~m}^{2}$ ).

b The results of CT2013B (http://www.esrl.noaa.gov/gmd/ccgg/carbontracker/CT2013B/) were derived from ftp://aftp.cmdl.noaa.gov/products/carbontracker/co2/fluxes/.

c The results of CTE2014 (CarbonTracker Europe; Peters et al., 2010) were derived from ftp://ftp.wur.nl/carbontracker/data/fluxes/.

sink of Europe in $2010\left(-1.02 \pm 0.30 \mathrm{Pg} \mathrm{C} \mathrm{yr}^{-1}\right)$ estimated by using satellite observations is much higher than previous inversion studies (e.g., Peylin et al., 2013) using only surface observations.

\section{Summary and conclusions}

In this study, to investigate the effect of the Siberian observations, which were not used in the previous studies using CarbonTracker, on the optimization of surface $\mathrm{CO}_{2}$ fluxes, two experiments (CNTL and JR) with different sets of observations from 2000 to 2009 were conducted and optimized surface $\mathrm{CO}_{2}$ fluxes from 2002 to 2009 were analyzed.

The global balances of the sources and sinks of surface $\mathrm{CO}_{2}$ fluxes were maintained with a similar trend for both experiments, while the distribution of the optimized surface $\mathrm{CO}_{2}$ fluxes changed. The magnitude of the optimized biosphere surface $\mathrm{CO}_{2}$ uptake and its uncertainty in EB (Siberia) was decreased from -1.17 to $-0.77 \pm 0.70{\mathrm{PgC} \mathrm{yr}^{-1}}^{-1}$, whereas it was increased in other regions of the NH (Eurasian temperate, Europe, North American boreal, and North American temperate). The land sink of Europe for 2008 and 2009 of the JR experiment increased significantly from $-0.30 \pm 0.68$ to $-0.75 \pm 0.63 \mathrm{Pg} \mathrm{C} \mathrm{yr}^{-1}$, which is consistent with the other inversion results (Reuter et al., 2014) inferred by satellite observations. Additional observations are used to correct the surface $\mathrm{CO}_{2}$ uptake in June and July, the active vegetation uptake season, in terms of monthly average optimized surface $\mathrm{CO}_{2}$ fluxes. As a result, the additional observations do not exhibit a change in the magnitude of the global surface $\mathrm{CO}_{2}$ flux balance because they provide detailed information about the Siberian land sink instead of the global land sink magnitude when they are used in our inversion modeling system (i.e., CarbonTracker).

The model $\mathrm{CO}_{2}$ concentrations using the background and optimized surface $\mathrm{CO}_{2}$ fluxes in the JR experiment are more consistent with the $\mathrm{CO}_{2}$ observations used in the optimization than those in the CNTL experiment, showing lower biases in the EB region. In contrast, the differences of biases of the two experiments in ET and Europe are smaller than those in EB. In comparison with vertical profiles of $\mathrm{CO}_{2}$ concentration observations which are not used in the optimization, the model $\mathrm{CO}_{2}$ concentrations in the JR experiment show smaller RMSD and MAE values, and a higher correlation coefficient than that in CNTL experiment.

The new observations provide information on the optimized surface $\mathrm{CO}_{2}$ fluxes. The observation impact of the Siberian observation data is investigated by means of uncertainty reduction and self-sensitivity calculated by an influence matrix. Additional observations reduce the uncer- 
tainty of the optimized surface $\mathrm{CO}_{2}$ fluxes in Asia and Europe, mainly in the EB region (Siberia), where the new observations are used in the assimilation. The average selfsensitivities of the JR-STATION sites are approximately $60 \%$ larger than those for other continuous measurements (e.g., tower measurements in North America). The global average self-sensitivity and cumulative impact of the JR experiment are higher than those of the CNTL experiment, which implies that the impact of JR-STATION data on optimized surface $\mathrm{CO}_{2}$ fluxes is higher than that of other observations used in both the CNTL and JR experiments. The RMSD of the analyzed surface $\mathrm{CO}_{2}$ fluxes constrained by 1 week of observations from the background fluxes also suggests that new Siberian observations provide information on the optimized surface $\mathrm{CO}_{2}$ fluxes.

This study shows that the JR-STATION data affect the longitudinal distribution of the total $\mathrm{NH}$ sinks, especially in the $\mathrm{EB}$ and Europe, when it is used by atmospheric $\mathrm{CO}_{2}$ inversion modeling. In the future, it is expected that Siberian observations will be used as an important constraint for estimating surface $\mathrm{CO}_{2}$ fluxes over the $\mathrm{NH}$ with various $\mathrm{CO}_{2}$ observations (e.g., satellite and aircraft measurements) simultaneously.

\section{Data availability}

CarbonTracker data are available at the NOAA (2017) CarbonTracker homepage: http://carbontracker. noaa.gov/. Observation data distributed by NOAA ESRL (2017) are available at the obspack homepage: doi:10.3334/OBSPACK/1001. WDCGG observation data are available at the WDCGG (2017) homepage: http://ds.data.jma.go.jp/wdcgg/. JR-STATION data are available at the CGER/NIES (2017) Global Environment database: http://db.cger.nies.go.jp/portal/geds/ atmosphericAndOceanicMonitoring. The model results are available upon request to the corresponding author.

Competing interests. The authors declare that they have no conflict of interest.

Acknowledgements. The authors appreciate the valuable comments of William Lahoz, Abhishek Chatterjee, and other reviewers. This study was funded by the Korea Meteorological Administration Research and Development Program under the grant KMIPA 2015-2021. The JR-STATION is supported by the Global Environment Research Account for National Institutes of the Ministry of the Environment, Japan and the Russian Foundation for Basic Research (grant no. 14-05-00590). The authors also acknowledge atmospheric $\mathrm{CO}_{2}$ measurement data providers and cooperating agencies at China Meteorological Administration, Commonwealth Scientific and Industrial Research Organization, Environment Canada, Finnish Meteorological Institute, Hungarian
Meteorological Service, Japan Meteorological Agency, Lawrence Berkeley National Laboratory, National Institute of Environmental Research, Norwegian Meteorological Institute, Max Planck Institute for Biogeochemistry, Morski Instytut Rybacki, National Center for Atmospheric Research, National Oceanic and Atmospheric Administration Earth System Research Laboratory, and Romanian Marine Research Institute.

Edited by: W. Lahoz

Reviewed by: A. C. Chatterjee and one anonymous referee

\section{References}

Berchet, A., Pison, I., Chevallier, F., Bousquet, P., Bonne, J.-L., and Paris, J.-D.: Objectified quantification of uncertainties in Bayesian atmospheric inversions, Geosci. Model Dev., 8, 15251546, doi:10.5194/gmd-8-1525-2015, 2015a.

Berchet, A., Pison, I., Chevallier, F., Paris, J.-D., Bousquet, P., Bonne, J.-L., Arshinov, M. Y., Belan, B. D., Cressot, C., Davydov, D. K., Dlugokencky, E. J., Fofonov, A. V., Galanin, A., Lavric, J., Machida, T., Parker, R., Sasakawa, M., Spahni, R., Stocker, B. D., and Winderlich, J.: Natural and anthropogenic methane fluxes in Eurasia: a mesoscale quantification by generalized atmospheric inversion, Biogeosciences, 12, 5393-5414, doi:10.5194/bg-12-5393-2015, 2015 b.

Boden, T., Marland, G., and Andres, R.: Global, regional, and national fossil-fuel $\mathrm{CO}_{2}$ emissions, Carbon Dioxide Information Analysis Center, Oak Ridge National Laboratory, US Department of Energy, Oak Ridge, TN, USA, 10, doi:10.3334/CDIAC/00001_V2010, 2010.

Bruhwiler, L. M. P., Michalak, A. M., and Tans, P. P.: Spatial and temporal resolution of carbon flux estimates for 1983-2002, Biogeosciences, 8, 1309-1331, doi:10.5194/bg-8-1309-2011, 2011.

CGER/NIES: JR-STATION data, available at: http://db.cger.nies. go.jp/portal/geds/atmosphericAndOceanicMonitoring, last access: 14 February 2017.

Ciais, P., Reichstein, M., Viovy, N., Granier, A., Ogée, J., Allard, V., Aubinet, M., Buchmann, N., Bernhofer, Chr., Carrara, A., Chevallier, F., De Noblet, N., Friend, A. D., Friedlingstein, P., Grünwald, T., Heinesch, B., Keronen, P., Knohl, A., Krinner, G., Loustau, D., Manca, G., Matteucci, G., Miglietta, F., Ourcival, J. M., Papale, D., Pilegaard, K., Rambal, S., Seufert, G., Soussana, J. F., Sanz, M. J., Schulze, E. D., Vesala, T., and Valentini, R.: Europe-wide reduction in primary productivity caused by the heat and drought in 2003, Nature, 529-533, doi:10.1038/nature03972, 2005.

Chevallier, F., Bréon, F.-M., and Rayner, P. J.: Contribution of the Orbiting Carbon Observatory to the estimation of $\mathrm{CO}_{2}$ sources and sinks: Theoretical study in a variational data assimilation framework, J. Geophys. Res.-Atmos., 112, D09307, doi:10.1029/2006JD007375, 2007.

Chevallier, F., Ciais, P., Conway, T. J., Aalto, T., Anderson, B. E., Bousquet, P., Brunke, E. G., Ciattaglia, L., Esaki, Y., Fröhlich, M., Gomez, A., Gomez-Pelaez, A. J., Haszpra, L., Krummel, P. B., Langenfelds, R. L., Leuenberger, M., Machida, T., Maignan, F., Matsueda, H., Morguí, J. A., Mukai, H., Nakazawa, T., Peylin, P., Ramonet, M., Rivier, L., Sawa, Y., Schmdit, M., Steele, L. P., Vay, S. A., Vermeulen, A. T., Wofsy, S., and Worthy, D.: $\mathrm{CO}_{2}$ sur- 
face fluxes at grid point scale estimated from a global 21 year reanalysis of atmospheric measurements, J. Geophys. Res.-Atmos., 115, D21307, doi 10.1029/2010jd013887, 2010.

Dolman, A. J., Shvidenko, A., Schepaschenko, D., Ciais, P., Tchebakova, N., Chen, T., van der Molen, M. K., Belelli Marchesini, L., Maximov, T. C., Maksyutov, S., and Schulze, E.-D.: An estimate of the terrestrial carbon budget of Russia using inventory-based, eddy covariance and inversion methods, Biogeosciences, 9, 5323-5340, doi:10.5194/bg-9-5323-2012, 2012.

Engelen, R. J., Denning, A. S., Gurney, K. R., and TransCom3 modelers: On error estimation in atmospheric $\mathrm{CO}_{2}$ inversions, J. Geophys. Res., 107, 4635, doi:10.1029/2002JD002195, 2002.

European Commission: Joint Research Centre (JRC)/Netherlands Environmental Assessment Agency (PBL): Emission Database for Global Atmospheric Research (EDGAR), release version 4.0, 2009.

Evensen, G.: Sequential data assimilation with a nonlinear quasigeostrophic model using Monte Carlo methods to forecast error statistics, J. Geophys. Res., 99, 10143-10162, 1994.

Feng, L., Palmer, P. I., Parker, R. J., Deutscher, N. M., Feist, D. G., Kivi, R., Morino, I., and Sussmann, R.: Estimates of European uptake of $\mathrm{CO}_{2}$ inferred from GOSAT $\mathrm{XCO}_{2}$ retrievals: sensitivity to measurement bias inside and outside Europe, Atmos. Chem. Phys., 16, 1289-1302, doi:10.5194/acp-16-12892016, 2016

Gurney, K. R., Law, R. M., Denning, A. S., Rayner, P. J., Baker, D., Bousquet, P., Bruhwiler, L., Chen, Y. H., Ciais, P., Fan, S., Fung, I. Y., Gloor, M., Heimann, M., Higuchi, K., John, J., Maki, T., Maksyutov, S., Masarie, K., Peylin, P., Prather, M., Pak, B. C., Randerson, J., Sarmiento, J., Taguchi, S., Takahashi, T., and Yuen, C. W.: Towards robust regional estimates of $\mathrm{CO}_{2}$ sources and sinks using atmospheric transport models, Nature, 415, 626630, 2002.

Hayes, D. J., McGuire, A. D., Kicklighter, D. W., Gurney, K. R., Burnside, T. J., and Melillo, J. M.: Is the northern high-latitude land-based $\mathrm{CO}_{2}$ sink weakening?, Global Biogeochem. Cy., 25, GB3018, doi:10.1029/2010GB003813, 2011.

Houghton, R. A., Butman, D., Bunn, A. G., Krankina, O. N., Schlesinger, P., and Stone, T. A.: Mapping Russian forest biomass with data from satellites and forest inventories, Environ. Res. Lett., 2, 045032, doi:10.1088/1748-9326/2/4/045032, 2007.

Houtekamer, P. L., and Mitchell, H. L.: A sequential ensemble Kalman filter for atmospheric data assimilation, Mon. Weather Rev., 129, 123-137, 2001.

Jacobson, A. R., Mikaloff Fletcher, S. E., Gruber, N., Sarmiento, J. L., and Gloor, M.: A joint atmosphere-ocean inversion for surface fluxes of carbon dioxide: 1. Methods and global-scale fluxes, Global Biogeochem. Cy., 21, B1019, doi:10.1029/2005GB002556, 2007.

Kim, J., Kim, H. M., and Cho, C.-H.: Application of Carbon Tracking System based on ensemble Kalman Filter on the diagnosis of Carbon Cycle in Asia, Atmosphere, 22, 415-447, 2012. (in Korean with English abstract)

Kim, J., Kim, H. M., and Cho, C.-H.: The effect of optimization and the nesting domain on carbon flux analyses in Asia using a carbon tracking system based on the ensemble Kalman filter, Asia-Pacific, J. Atmos. Sci., 50, 327-344, doi:10.1007/s13143014-0020-y, 2014a.
Kim, J., Kim, H. M., and Cho, C.-H.: Influence of $\mathrm{CO}_{2}$ observations on the optimized $\mathrm{CO}_{2}$ flux in an ensemble Kalman filter, Atmos. Chem. Phys., 14, 13515-13530, doi:10.5194/acp-1413515-2014, 2014b.

Knorr, W., Gobron, N., Scholze, M., Kaminski, T., Schnur, R., and Pinty, B.: Impact of terrestrial biosphere carbon exchanges on the anomalous $\mathrm{CO}_{2}$ increase in 2002-2003, Geophys. Res. Lett., 34, L09703, doi:10.1029/2006GL029019, 2007.

Krol, M., Houweling, S., Bregman, B., van den Broek, M., Segers, A., van Velthoven, P., Peters, W., Dentener, F., and Bergamaschi, P.: The two-way nested global chemistry-transport zoom model TM5: algorithm and applications, Atmos. Chem. Phys., 5, 417432, doi:10.5194/acp-5-417-2005, 2005.

Kurganova, I. N., Kudeyarov, V. N., and Lopes De Gerenyu, V. O.: Updated estimate of carbon balance on Russian territory, Tellus B, 62, 497-505, doi:10.1111/j.1600-0889.2010.00467.x, 2010.

Le Quéré, C., Moriarty, R., Andrew, R. M., Peters, G. P., Ciais, P., Friedlingstein, P., Jones, S. D., Sitch, S., Tans, P., Arneth, A., Boden, T. A., Bopp, L., Bozec, Y., Canadell, J. G., Chini, L. P., Chevallier, F., Cosca, C. E., Harris, I., Hoppema, M., Houghton, R. A., House, J. I., Jain, A. K., Johannessen, T., Kato, E., Keeling, R. F., Kitidis, V., Klein Goldewijk, K., Koven, C., Landa, C. S., Landschützer, P., Lenton, A., Lima, I. D., Marland, G., Mathis, J. T., Metzl, N., Nojiri, Y., Olsen, A., Ono, T., Peng, S., Peters, W., Pfeil, B., Poulter, B., Raupach, M. R., Regnier, P., Rödenbeck, C., Saito, S., Salisbury, J. E., Schuster, U., Schwinger, J., Séférian, R., Segschneider, J., Steinhoff, T., Stocker, B. D., Sutton, A. J., Takahashi, T., Tilbrook, B., van der Werf, G. R., Viovy, N., Wang, Y.-P., Wanninkhof, R., Wiltshire, A., and Zeng, N.: Global carbon budget 2014, Earth Syst. Sci. Data, 7, 47-85, doi:10.5194/essd-7-47-2015, 2015.

Lloyd, J., Langenfelds, R. L., Francey, R. J., Gloor, M., Tchebakova, N. M., Zolotoukhine, D., Brand, W. A., Werner, R. A., Jordan, A., Allison, C. A., Zrazhewske, V., Shibistova, O., and Schulze, E.D.: A trace-gas climatology above Zotino, central Siberia, Tellus B, 54, 749-767, 2002.

Machida, T., Matsueda, H., Sawa, Y., Nakagawa, Y., Hirotani, K., Kondo, N., Goto, K., Nakazawa, T., Ishikawa, K., and Ogawa, T.: Worldwide Measurements of Atmospheric $\mathrm{CO}_{2}$ and Other Trace Gas Species Using Commercial Airlines, J. Atmos. Ocean. Tech., 25, 1744-1754, doi:10.1175/2008JTECHA1082.1, 2008.

Machida, T., Tohjima, Y., Katsumata, K., and Mukai, H.: A new $\mathrm{CO}_{2}$ calibration scale based on gravimetric one-step dilution cylinders in National Institute for Environmental Studies-NIES $09 \mathrm{CO}_{2}$ scale, Report of the 15th WMO/IAEA Meeting of Experts on Carbon Dioxide, Other Related Tracer Measurement Techniques, GAW Rep. 194, 165-169, World Meteorological Organization, Geneva, Switzerland, 2011.

Maki, T., Ikegami, M., Fujita, T., Hirahara, T., Yamada, K., Mori, K., Takeuchi, A., Tsutsumi, Y., Suda, K., and Conway, T. J.: New technique to analyse global distributions of $\mathrm{CO}_{2}$ concentrations and fluxes from non-processed observational data, Tellus B, 62, 797-809, doi:10.1111/j.1600-0889.2010.00488.x, 2010.

Maksyutov, S., Machida, T., Mukai, H., Patra, P. K., Nakazawa, T., Inoue, G., and Transcom-3 Modelers: Effect of recent observations on Asia $\mathrm{CO}_{2}$ flux estimates by transport model inversions, Tellus B, 55, 522-529, 2003.

Masarie, K. A., Peters, W., Jacobson, A. R., and Tans, P. P.: ObsPack: a framework for the preparation, delivery, and attribution 
of atmospheric greenhouse gas measurements, Earth Syst. Sci. Data, 6, 375-384, doi:10.5194/essd-6-375-2014, 2014.

Miller, C. E., Crisp, D., DeCola, P. L., Olsen, S. C., Randerson, J. T., Michalak, A. M., Alkhaled, A., Rayner, P., Jacob, D. J., Suntharalingam, P., Jones, D. B. A., Denning, A. S., Nicholls, M. E., Doney, S. C., Pawson, S., Boesch, H., Connor, B. J., Fung, I. Y., O'Brien, D. O., Salawitch, R. J., Sander, S. P., Sen, B., Tans, P., Toon, G. C., Wennberg, P. O., Wofsy, S. C., Yung, Y. L., and Law, R. M.: Precision requirements for space-based $\mathrm{XCO}_{2}$ data, J. Geophys. Res., 112, D10314, doi:10.1029/2006JD007659, 2007.

NOAA: CarbonTracker data, available at: http://carbontracker.noaa. gov/, last access: 14 February 2017.

NOAA ESRL: Observation data, available at: doi:10.3334/OBSPACK/1001, last access: 14 February 2017.

Olson, J., Watts, J., and Allsion, L.: Major World Ecosystem Complexes Ranked by Carbon in Live Vegetation: a Database, Tech. rep., Carbon Dioxide Information Analysis Center, U.S. Department of Energy, Oak Ridge National Laboratory, Oak Ridge, TN, USA, doi:10.3334/CDIAC/lue.ndp017, 1992.

Olsen, S. C. and Randerson, J. T.: Differences between surface and column atmospheric $\mathrm{CO}_{2}$ and implications for carbon cycle research, J. Geophys. Res., 109, D02301, doi:10.1029/2003JD003968, 2004.

Paris, J.-D., Ciais, P., Nédélec, P., Ramonet, M., Belan, B. D., Arshinov, M. Y., Golitsyn, G. S., Granberg, I., Stohl, A., Cayez, G., Athier, G., Boumard, F., and Cousin, J. M.: The YAK-AEROSIB transcontinental aircraft campaigns: new insights on the transport of $\mathrm{CO}_{2}, \mathrm{CO}$ and $\mathrm{O}_{3}$ across Siberia, Tellus B, 60, 551-568, 2008.

Peters, W., Jacobson, A. R., Sweeney, C., Andrews, A. E., Conway, T. J., Masarie, K., Miller, J. B., Bruhwiler, L. M. P., Petron, G., Hirsch, A. I., Worthy, D. E. J., van der Werf, G. R., Randerson, J. T., Wennberg, P. O., Krol, M. C., and Tans, P. P.: An atmospheric perspective on North American carbon dioxide exchange: CarbonTracker, P. Natl. Acad. Sci. USA, 104, 18925-18930, 2007.

Peters, W., Krol, M. C., van der Werf, G. R., Houweling, S., Jones, C. D., Hughes, J., Schaefer, K., Masarie, K. A., Jacobson, A. R. Miller, J. B., Cho, C. H., Ramonet, M., Schmidt, M., Ciattaglia, L., Apadula, F., Heltai, D., Meinhardt, F., di Sarra, A. G., Piacentino, S., Sferlazzo, D., Aalto, T., Hatakka, J., Str?m, J., Haszpra, L., Meijer, H. A. J., van der Laan, S., Neubert, R. E. M., Jordan, A., Rod, X., Morguí, J. A., Vermeulen, A. T., Popa, E., Rozanski, K., Zimnoch, M., Manning, A. C., Leuenberger, M., Uglietti, C., Dolman, A. J., Ciais, P. Heimann, M., and Tans, P. P.: Seven years of recent European net terrestrial carbon dioxide exchange constrained by atmospheric observations, Glob. Change Biol., 16, 1317-1337, doi:10.1111/j.13652486.2009.02078.x, 2010.

Peylin, P., Law, R. M., Gurney, K. R., Chevallier, F., Jacobson, A. R., Maki, T., Niwa, Y., Patra, P. K., Peters, W., Rayner, P. J., Rödenbeck, C., van der Laan-Luijkx, I. T., and Zhang, X.: Global atmospheric carbon budget: results from an ensemble of atmospheric $\mathrm{CO}_{2}$ inversions, Biogeosciences, 10, 6699-6720, doi:10.5194/bg-10-6699-2013, 2013.

Quegan, S., Beer, C., Shvidenko, A., McCallum, I., Handoh, I. C., Peylin, P., Rödenbeck, C., Lucht, W., Nilsson, S., and Schmullius, C.: Estimating the carbon balance of central Siberia using landscape-ecosystem approach, atmospheric inversion and dynamic global vegetation models, Glob. Change Biol., 17, 351365, doi:10.1111/j.1365-2486.2010.02275.x, 2011.
Reuter, M., Buchwitz, M., Hilker, M., Heymann, J., Schneising, O., Pillai, D., Bovensmann, H., Burrows, J. P., Bösch, H., Parker, R., Butz, A., Hasekamp, O., O’Dell, C. W., Yoshida, Y., Gerbig, C., Nehrkorn, T., Deutscher, N. M., Warneke, T., Notholt, J., Hase, F., Kivi, R., Sussmann, R., Machida, T., Matsueda, H., and Sawa, Y.: Satellite-inferred European carbon sink larger than expected, Atmos. Chem. Phys., 14, 13739-13753, doi:10.5194/acp-1413739-2014, 2014.

Saeki, T., Maksyutov, S., Sasakawa, M., Machida, T., Arshinov, M., Tans, P. P., Conway, T. J., Saito, M., Valsala, V., Oda, T., Andres, R. J., and Belikov, D.: Carbon flux estimation for Siberia by inverse modeling constrained by aircraft and tower $\mathrm{CO}_{2}$ measurements, J. Geophys. Res.-Atmos., 118, 1100-1122, doi:10.1002/jgrd.50127, 2013.

Sasakawa, M., Shimoyama, K., Machida, T., Tsuda, N., Suto, H., Arshinov, M., Davydov, D., Fofonov, A., Krasnov, O., Saeki, T., Koyama, Y., and Maksyutov, S.: Continuous measurements of methane from a tower network over Siberia, Tellus B, 62, 403416, doi:10.1111/j.1600-0889.2010.00494.x, 2010.

Sasakawa, M., Machida, T., Tsuda, N., Arshinov, M., Davydov, D., Fofonov, A., and Krasnov, O.: Aircraft and tower measurements of $\mathrm{CO}_{2}$ concentration in the planetary boundary layer and the lower free troposphere over southern taiga in West Siberia: Longterm records from 2002 to 2011, J. Geophys. Res.-Atmos., 118, 9489-9498, doi:10.1002/jgrd.50755, 2013.

Schepaschenko, D., McCallum, I., Shvidenko, A., Fritz, S., Kraxner, F., and Obersteiner, M.: A new hybrid land cover dataset for Russia: a methodology for integrating statistics, remote sensing and in situ information, J. Land Use Sci., 6, 245259, doi:10.1080/1747423X.2010.511681, 2011.

Schneising, O., Buchwitz, M., Reuter, M., Heymann, J., Bovensmann, H., and Burrows, J. P.: Long-term analysis of carbon dioxide and methane column-averaged mole fractions retrieved from SCIAMACHY, Atmos. Chem. Phys., 11, 2863 2880, doi:10.5194/acp-11-2863-2011, 2011.

Schulze, E.-D., Lloyd, J., Kelliher, F. M., Wirth, C., Rebmann, C., Lühker, B., Mund, M., Knohl, A., Milyukova, I. M., Schulze, W., Ziegler, W., Varlagin, A. B., Sogachev, A. F., Valentini, R., Dore, S., Grigoriev, S., Kolle, O., Panfyorov, M. I., Tchebakova, N., and Vygodskaya, N. N.: Productivity of forests in the Eurosiberian boreal region and their potential to act as a carbon sink - a synthesis, Glob. Change Biol., 5, 703-722, doi:10.1046/j.13652486.1999.00266.x, 1999.

Tarnocai, C., Canadell, J. G., Schuur, E. A. G., Kuhry, P., Mazhitova, G., and Zimov, S.: Soil organic carbon pools in the northern circumpolar permafrost region, Global Biogeochem. Cy., 23, GB2023, doi:10.1029/2008GB003327, 2009.

Turnbull, J. C., Miller, J. B., Lehman, S. J., Hurst, D., Peters, W., Tans, P. P., Southon, J., Montzka, S. A., Elkins, J. W., Mondeel, D. J., Romashkin, P. A., Elansky, N., and Skorokhod, A.: Spatial distribution of $\Delta^{14} \mathrm{CO}_{2}$ across Eurasia: measurements from the TROICA-8 expedition, Atmos. Chem. Phys., 9, 175187, doi:10.5194/acp-9-175-2009, 2009.

van der Laan-Luijkx, I. T., van der Velde, I. R., Krol, M. C., Gatti, L. V., Domingues, L. G., Correia, C. S. C., Miller, J. B., Gloor, M., van Leeuwen, T. T., Kaiser, J. W., Wiedinmyer, C., Basu, S., Clerbaux, C., and Peters, W.: Response of the Amazon carbon balance to the 2010 drought derived with Carbon- 
Tracker South America, Global Biogeochem. Cy., 29, 10921108, doi:10.1002/2014GB005082, 2015.

van der Werf, G. R., Randerson, J. T., Giglio, L., Collatz, G. J., Mu, M., Kasibhatla, P. S., Morton, D. C., DeFries, R. S., Jin, Y., and van Leeuwen, T. T.: Global fire emissions and the contribution of deforestation, savanna, forest, agricultural, and peat fires (19972009), Atmos. Chem. Phys., 10, 11707-11735, doi:10.5194/acp10-11707-2010, 2010.

WDCGG: WDCGG observation data, available at: http://ds.data. jma.go.jp/wdcgg/, last access: 14 February 2017.

Whitaker, J. S. and Hamill, T. M.: Ensemble Data Assimilation without Perturbed Observations, Mon. Weather Rev., 130, 19131924, 2002.

Winderlich, J., Chen, H., Gerbig, C., Seifert, T., Kolle, O., Lavric, J. V., Kaiser, C., Höfer, A., and Heimann, M.: Continuous lowmaintenance $\mathrm{CO}_{2} / \mathrm{CH}_{4} / \mathrm{H}_{2} \mathrm{O}$ measurements at the Zotino Tall Tower Observatory (ZOTTO) in Central Siberia, Atmos. Meas. Tech., 3, 1113-1128, doi:10.5194/amt-3-1113-2010, 2010.
Zhang, H. F., Chen, B. Z., van der Laan-Luijkx, I. T., Chen, J., Xu, G., Yan, J. W., Zhou, L. X., Fukuyama, Y., Tans, P. P., and Peters, W.: Net terrestrial $\mathrm{CO}_{2}$ exchange over China during 20012010 estimated with an ensemble data assimilation system for atmospheric $\mathrm{CO}_{2}$, J. Geophys. Res.-Atmos., 119, 2013JD021297, doi:10.1002/2013JD021297, 2014a.

Zhang, H. F., Chen, B. Z., van der Laan-Luijk, I. T., Machida, T., Matsueda, H., Sawa, Y., Fukuyama, Y., Langenfelds, R., van der Schoot, M., Xu, G., Yan, J. W., Cheng, M. L., Zhou, L. X., Tans, P. P., and Peters, W.: Estimating Asian terrestrial carbon fluxes from CONTRAIL aircraft and surface $\mathrm{CO}_{2}$ observations for the period 2006-2010, Atmos. Chem. Phys., 14, 5807-5824, doi:10.5194/acp-14-5807-2014, 2014b. 